Notre Dame Law School

NDLScholarship

Journal Articles

Publications

$7-1-2015$

\title{
The Hughes Court Docket Books: The Early Terms, 1929-1933
}

Barry Cushman

Notre Dame Law School, bcushman@nd.edu

Follow this and additional works at: https://scholarship.law.nd.edu/law_faculty_scholarship

Part of the Judges Commons, and the Legal History Commons

\section{Recommended Citation}

Barry Cushman, The Hughes Court Docket Books: The Early Terms, 1929-1933, 40 J. Sup. Ct. Hist. 103-32 (2015).

Available at: https://scholarship.law.nd.edu/law_faculty_scholarship/1212

This Article is brought to you for free and open access by the Publications at NDLScholarship. It has been accepted for inclusion in Journal Articles by an authorized administrator of NDLScholarship. For more information, please contact lawdr@nd.edu. 


\section{The Hughes Court Docket Books: The Early Terms, 1929-1933}

\section{BARRY CUSHMAN}

For many years, the docket books kept by a number of the Hughes Court Justices have been held by the Office of the Curator of the Supreme Court. Yet the existence of these docket books was not widely known, and access to them was highly restricted. In April of 2014, however, the Court adopted new guidelines designed to increase access to the docket books for researchers. This article offers a report and analysis based on a review of all of the docket books that the Curator's Office holds for the early Hughes Court, comprising the 1929-1933 Terms. Only one of the entries in these docket books has been examined and reported on before. ${ }^{1}$

This article canvasses the available docket book entries relevant to what scholars commonly regard as the major decisions of the early Hughes Court. ${ }^{2}$ This review includes fifty-nine cases concerning areas of law as diverse as the Commerce Clause, the dormant Commerce Clause, substantive due process, equal protection, fair trade, labor relations, intergovernmental tax immunities, criminal procedure, civil rights, and civil liberties. The information in the docket books sheds particularly fascinating new light on decisions such as Nebbia v. New York, ${ }^{3}$ Home Bldg. \& Loan Assn. v. Blaisdell, ${ }^{4}$ New State Ice Co. v. Liebmann, ${ }^{5}$ Powell v. Alabama, ${ }^{6}$ Nixon v. Condon, ${ }^{7}$ and Burnet v. Coronado Oil \& $\mathrm{Gas} \mathrm{Co}^{8}$ In addition, for these and the many other cases examined, this article also reports on whether a unanimous decision was also free from dissent at conference or became so only because one or more Justices acquiesced in the judgment of their colleagues, as well as on whether nonunanimous decisions were divided by the same vote and with the same alliances at conference. The docket books also provide records of instances in which a case that initially was assigned to one Justice was later reassigned to another. These records afford us some insight into the kinds of cases in which this tended to occur, and provide an opportunity to document for the first time the long held suspicion that the notoriously slowwriting Justice Van Devanter frequently was relieved of his opinions by the Chief Justice. 


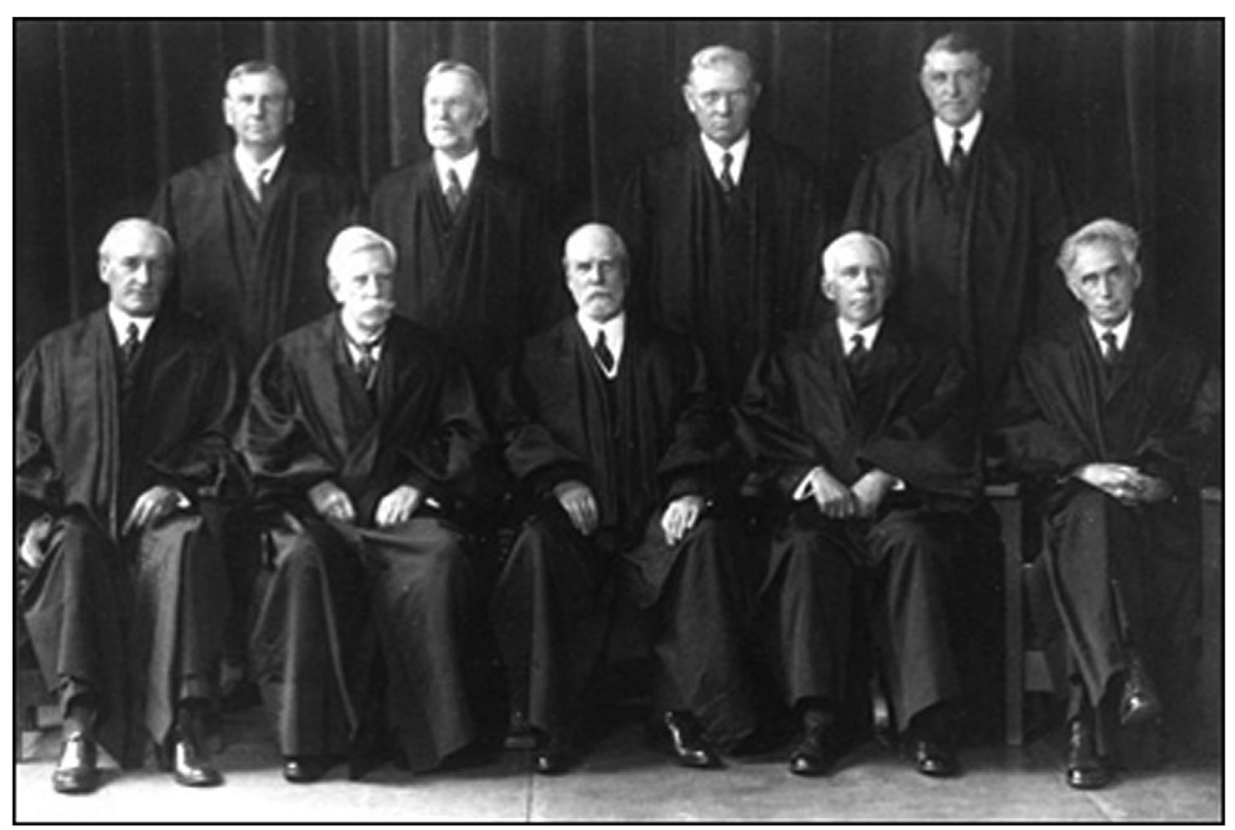

By examining the docket books for the early Hughes Court (pictured in 1930), comprising the 1929-1933 Terms, the author was able to report whether a unanimous decision was also free from dissent at conference or became so only because one or more Justices acquiesced in the judgment of their colleagues, as well as on whether non-unanimous decisions were divided by the same vote and with the same alliances at conference. The docket books also provide records of instances in which a case that initially was assigned to one Justice was later reassigned to another.

A review of the early Hughes Court docket books also makes possible two contributions to the political science literature on judicial behavior. The first is to the scholarship on vote fluidity and unanimity norms in the Supreme Court. It is widely agreed that the period from the Chief Justiceship of John Marshall through that of Charles Evans Hughes was characterized by a "norm of consensus," "marked by individual justices accepting the Court's majority opinions." 9 It is generally believed that this norm of consensus collapsed early in the Chief Justiceship of Harlan Fiske Stone, ${ }^{10}$ though some scholars have pointed to causes that antedate Stone's elevation to the center chair. ${ }^{11}$ Still others have suggested that there may have been "an earlier, more gradual change in norms" on the late Taft and Hughes Courts. ${ }^{12}$ Political scientists who have had access to the docket books of various Justices serving on other Courts have demonstrated that much of the consensus achieved by the Court throughout its history has resulted from the decision of Justices who had dissented at conference to join the majority's ultimate disposition. A substantial body of literature shows that Justices commonly have changed their votes between the conference and the final vote on the merits. ${ }^{13}$

Of the different types of vote fluidity between the conference vote and the final vote on the merits in major early Hughes Court cases, by far the most common was for a Justice to move from a dissenting or passing vote to a vote with the ultimate majority. An examination of the docket books permits us to illuminate several features of this phenomenon: the major cases in which it occurred, how frequently it occurred in major cases, the frequency with which each of the Justices did so, and the comparative success of early Hughes Court Justices in preparing majority opinions that would either enlarge 


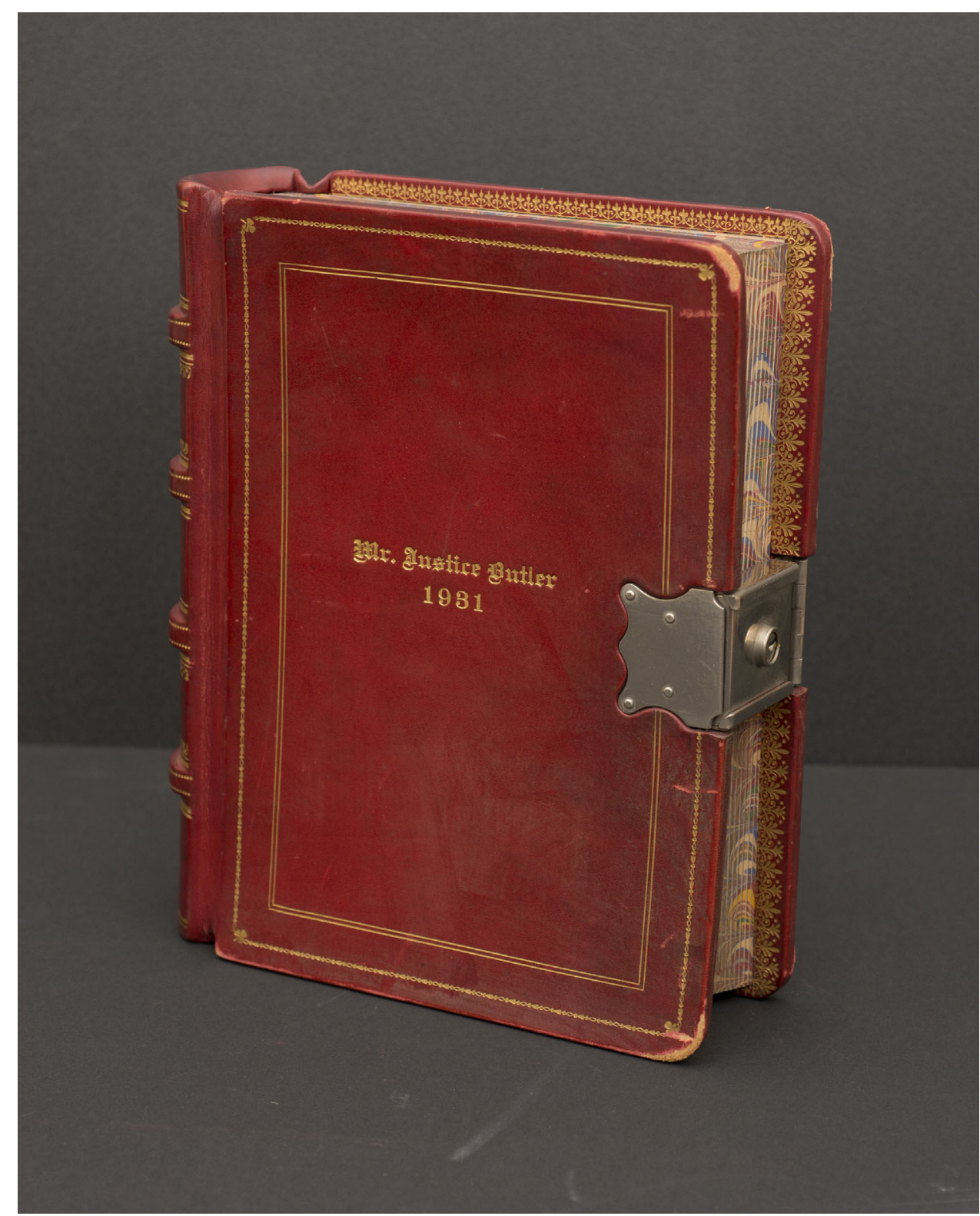

The Justices have traditionally used special docket books to record votes and take notes on case deliberations in Conference. Bound red-leather books embossed in gold with a hefty locket, such as this one belonging to Pierce Butler, came into use in the 1870 s and were issued by the Government Printing Office until the 1940s.

the size of the ultimate winning coalition or produce ultimate unanimity from a divided conference.

The second contribution concerns the behavior of newcomers to the Court. In 1958, Eloise C. Snyder published an article in which she concluded that new members of the Court tended initially to affiliate with a moderate, "pivotal clique" before migrating to a more clearly ideological liberal or conservative bloc. ${ }^{14}$ Seven years later, J. Woodford Howard argued that Justice Frank Murphy's first three Terms on the Court were marked by a "freshman effect" characterized by an "instability" in his decision making that rendered the Justice "diffident to the point 
of indecisiveness." 15 These studies in turn spawned a literature on the "freshman" or "acclimation" effect for Justices new to the Court. These studies generally characterize the freshman effect "as consisting of one or more of the following types of behavior: (1) initial bewilderment or disorientation, (2) assignment of a lower than average number of opinions to the new justices, and (3) an initial tendency on the part of the new justice to join a moderate block of justices." 16 While some studies have confirmed the existence of some feature or another of the freshman effect, ${ }^{17}$ others have cast significant doubt on the hypothesis, maintaining that it is either non-existent or confined to limited circumstances. ${ }^{18}$ Studies of the freshman period for individual Justices on the whole have not lent much support to the hypothesis. ${ }^{19}$

Professor Howard suggested that the freshman effect might also be manifested by a tendency of new Justices to change their votes between the conference vote and the final vote on the merits. Howard listed a number of considerations that might prompt a Justice to shift ground in this manner, but first among them were "unstable attitudes that seem to have resulted from the process of assimilation to the Court." For instance, he remarked, "Justice Cardozo, according to one clerk's recollection of the docket books ... frequently vot[ed] alone in conference before ultimately submerging himself in a group opinion." 20 Howard reported that Justice Murphy exhibited "a similar instability" during his freshman years on the Court. ${ }^{21}$ Subsequent studies from the Vinson, Warren, and Burger Court docket books have produced divergent conclusions with respect to this reputed feature of the freshman effect. ${ }^{22}$

The only freshman Justices on the early Hughes Court were Owen J. Roberts, appointed in 1930, and Benjamin N. Cardozo, appointed in $1932 .{ }^{23}$ A review of the voting behavior of these newcomers to the Court does not disclose any appreciable freshman effect with respect to voting fluidity. Instead, one finds that, in the major cases examined here, these two Justices were among the least likely to change their positions between the conference vote and the final vote on the merits.

\section{The Early Hughes Court Justices and Their Docket Books}

The early Hughes Court was a remarkably stable Court. After Hughes was confirmed to the center chair on February 13, $1930,{ }^{24}$ and three months later Roberts was confirmed to the seat vacated by the untimely death of Edward Terry Sanford, ${ }^{25}$ the Court saw only one personnel change over the next seven years. Oliver Wendell Holmes, Jr. retired on January 12, 1932, ${ }^{26}$ and Cardozo was confirmed as his successor on March 2 of that year. ${ }^{27}$ Hughes, Roberts, and Cardozo joined six holdovers from the Taft Court: Justices Van Devanter, James Clark McReynolds, Louis D. Brandeis, George Sutherland, Pierce Butler, and Stone. This was the Court that would encounter the legislative and regulatory responses to the ravages of the Great Depression.

The Office of the Curator has in its collection the docket books of five of the early Hughes Court Justices. Unfortunately, the docket books of Chief Justice Hughes and Justices Holmes and Sutherland do not appear to have survived. During this period Justice McReynolds burned his docket books at the conclusion of each Term, ${ }^{28}$ and Paul Freund, who clerked for Justice Brandeis during the 1932 Term, reports that his Justice did the same. ${ }^{29}$ But the collection does have a complete run of the docket books of Justice Stone, from the 1929 through the 1933 Terms. The Stone docket books contain records of the conference votes in most cases, and occasionally some notes on the remarks made by colleagues during conference discussions. Unfortunately, Stone's handwriting 
is very difficult to decipher, so the content of these notes too often remains obscure. The collection also has nearly a complete run of the docket books for Justice Roberts, including the 1930-1933 Terms. The Roberts docket books similarly contain records of the conference votes in most cases, along with an occasional but none-too-frequent note on conference discussions.

The Curator's collection likewise contains a nearly complete run of Pierce Butler's docket books, including the 1931-1933 Terms. Unfortunately, the Butler docket book for the 1930 Term does not appear to have survived. Butler's docket books provide not only a record of conference votes, but also a remarkably rich set of notes on conference discussions. The collection contains as well Justice Cardozo's docket book for the 1932 Term, which has records of some conference votes but no significant notes on conference discussion. Finally, the collection holds Van Devanter's docket books for the 1931 and 1933 Terms. Though these docket books contain entries for most of the cases decided by the Court during those terms, they contain no records of conference votes or conference discussion. As a consequence, they are of little use to the historical researcher. ${ }^{30}$

In discussing the post-conference voting behaviors of the early Hughes Court Justices, I will be using several defined terms. I shall use the term acquiescence to denote instances in which a Justice who either dissented or passed at conference ultimately joined in the majority's disposition. ${ }^{31}$ In other words, acquiescence denotes instances in which a Justice who was not with the majority at conference moved toward the majority. I will refer to movements from dissent at conference to the majority in the final vote on the merits $^{32}$ as instances of strong acquiescence, and to movements from a passing vote at conference to the majority in the final vote on the merits as instances of weak acquiescence. ${ }^{33}$ Of course, such movement might have occurred either because the Justice in question became persuaded that the majority was correct, or because, though remaining unpersuaded, he elected to go along with the majority for the sake of some other consideration such as collegiality or public perception. $^{34}$ The information contained in the docket books does not enable us to discriminate between these two possibilities, and therefore I shall not attempt to do so here. I will use the term non-acquiescence to denote instances in which a Justice who dissented at conference remained steadfast in his opposition to the majority's disposition. In cases of non-acquiescence, there was no post-conference change in the vote of the Justice in question. I will use the term quasi-acquiescence to denote a situation in which a Justice who was inclined in conference to oppose the majority's disposition withheld his dissent and instead publicly concurred in the result with the written statement that he was doing so only because he felt bound by the authority of an earlier decision with which he disagreed. Finally, I will use the term defection to denote instances in which a Justice who was either a member of the conference majority or passed at conference later dissented from the published opinion. ${ }^{35}$ In other words, defection denotes instances in which the Justice in question moved away from the majority. Again, I will refer to movements from the majority at conference to dissent in the final vote on the merits as instances of strong defection, and to movements from a passing vote at conference to the majority in the final vote on the merits as instances of weak defection. ${ }^{36}$

\section{The Cases}

\section{Unanimous Decisions with No Vote Changes}

There were several cases from the early Terms of the Hughes Court in which the Justices unanimously upheld state exercises of the police power or the taxing power in the 
face of challenges under the Fourteenth Amendment and/or the dormant Commerce Clause. The vote in each of these cases was also unanimous at conference. ${ }^{37}$ For instance, Magnano Co. v. Hamilton ${ }^{38}$ upheld a state tax on butter substitutes. Hughes opened the conference discussion of Magnano by saying, "Would have to be a very strong case to hold tax invalid as excessive." Butler records that Van Devanter, McReynolds, and Brandeis agreed with the Chief Justice. McReynolds apparently mentioned McCray v. United States, a 1904 decision that had upheld a steep federal excise tax on oleomargarine colored to resemble butter. At this point Van Devanter interjected that "fed \& state taxes not on same plane."39

Several cases contributed to the line of authority distinguishing production from commerce in both affirmative and dormant Commerce Clause jurisprudence, and would soon be relied upon by the Court in a major New Deal decision limiting federal regulatory authority. ${ }^{40}$ In Utah Power \& Light Co. v. Pfost ${ }^{41}$ for example, the Court unanimously upheld a state tax on the production of electricity to be transmitted outside the state of production, despite the fact that interstate and intrastate generation were inseparable. Butler records Hughes characterizing the measure as an "Occupation tax," and noting that "There is an intra[state] activity." 42

The flip side of this local/national distinction, of course, was that Congress enjoyed significant authority to regulate the interstate activities of common carriers. Three railway regulation cases decided by unanimous conference vote illustrate this principle. In Texas \& New Orleans Railway Co. v. Brotherhood of Railway Clerks, ${ }^{43}$ the Court unanimously upheld the self-organization provisions of the Railway Labor Act of 1926. And in two decisions applying the doctrine of the Shreveport Rate Case, ${ }^{44}$ the Court unanimously upheld the power of the Interstate Commerce Commission (ICC) to raise intrastate rates for rail shipment in order to prevent discrimination against interstate commerce. $^{45}$

Another major question of structural constitutional law also produced unanimity. In Monaco $v$. Mississippi, ${ }^{46}$ the Court unanimously held that it had no jurisdiction over a suit brought by a foreign sovereign against a state of the United States without that state's consent. The suit was to recover principal and interest on government securities that had been issued in the 1830s, and had matured between 1850 and $1866 .{ }^{47}$ At the conference, Hughes observed that there was no statute of limitation governing the claim. He noted, "This is first case brought by foreign," and encouraged his colleagues to "lay down the proposition that no foreign can sue one of our states without its consent."48 There was some disagreement among those in the majority concerning the proper rationale for the decision. Van Devanter, Sutherland, and Butler favored resting the decision on "laches," maintaining that Monaco was presenting a "stale claim."49 Hughes agreed that "as to laches in much trouble" but preferred to use the opinion to clarify the broader jurisdictional issue. ${ }^{50}$ Brandeis, Roberts, and Cardozo agreed with the comments of the Chief Justice, ${ }^{51}$ and, though Stone did not record the rationale for his own vote, Butler and Roberts record him as concurring with the views expressed by Hughes. ${ }^{52}$ The Chief's theory of the case found expression in his opinion for the Court, which contains no reference to the doctrine of laches.

There also were a number of cases concerning criminal law and criminal procedure in which the votes both at conference and in the published opinion were unanimous. ${ }^{53}$ For example, Nathanson v. United States $^{54}$ invalidated a warrant to search a private dwelling for liquor on the ground that it had been issued based on mere belief and suspicion rather than upon probable cause, while Quercia v. United States ${ }^{55}$ overturned a narcotics conviction where the trial judge's charge to the jury had expressed the view that 
the accused's testimony consisted almost entirely of perjury.

Finally, all of the Justices agreed in Cochran v. Board of Education ${ }^{56}$ that taxation to support provision of non-sectarian school books to children attending parochial schools did not constitute a taking of private property for a private purpose in violation of the Fourteenth Amendment.

\section{Unanimous Decisions with Vote Changes}

The Justices of the early Hughes Court also often managed to produce a united public front even where they had been divided in conference. In four cases involving state regulatory power, a Justice who had disagreed or passed at the conference vote ultimately joined the opinion of the Court. In Smith v. Cahoon, ${ }^{57}$ the Court unanimously reversed a judgment upholding a statute requiring private carriers for hire to obtain certificates of necessity in order to use public highways. At the conference, however, McReynolds passed, and Stone recorded the disposition as "Tentative." Blasius $^{59}$ unanimously upheld that state's taxation of cattle bought in another state and held briefly before resale, but at conference Sutherland was not with the majority. Though P.F. Petersen Baking Co. v. Bryan ${ }^{60}$ unanimously upheld a Nebraska statute regulating bread weights, Stone and Butler record that Van Devanter passed at the conference vote. And while W. B. Worthen Co. v. Thomas ${ }^{61}$ unanimously invalidated as a violation of the Contracts Clause a debtor exemption statute applied retroactively, Stone had passed when the case was voted on in conference.

Two seminal interpretations of the Federal Trade Commission Act similarly managed to elicit acquiescence from a conference holdout. In Federal Trade Commission v. Algoma Lumber Co., ${ }^{62}$ McReynolds, who had passed at conference, ultimately joined the Court's opinion holding that competition may be "unfair" within the meaning of the Act even if it does not constitute actual fraud and even if the consumer suffers no financial injury. McReynolds also joined the unanimous opinion in Federal Trade Commission v. R.F. Keppel \& Bro., ${ }^{63}$ even though he had been the lone dissenter at conference. There the Court held that a practice may be "unfair" within the meaning of the Act even if it does not involve any fraud or deception, and even though competitors may maintain their competitive position by adopting it.

The Justices of the early Hughes Court also forged a united front despite disagreements in conference in two significant federalism cases. In Fox Film Corp. v. Doyal $^{64}$ the Court unanimously held that revenue from copyrights issued by the federal government were not exempt from state taxation under the doctrine of intergovernmental tax immunity. At the conference, however, McReynolds and Sutherland had voiced contrary views. Those two Justices also had cast dissenting votes at the conference on United States v. Louisiana, ${ }^{65}$ which upheld an ICC order raising intrastate rates, though Stone recorded a question mark next to Sutherland's vote, indicating that Sutherland was uncertain of his position. Brandeis passed at the conference vote, raising the prospect of three dissenting votes. Indeed, it appears that Brandeis was inclined toward the dissenting views expressed by McReynolds. Butler's record indicates " 4 [Brandeis] $=3$ [McReynolds]." ${ }^{, 66}$ In the end, however, each of these three Justices acquiesced in the judgment of the majority.

The same pattern of acquiescence can be seen in contemporary cases involving criminal law and criminal procedure. In United States v. LaFranca, ${ }^{67}$ a case that figured prominently in the recent decision of NFIB $v$. Sebelius,${ }^{68}$ the Court unanimously construed a putative "tax" under the Prohibition Act as not truly a tax but instead a "penalty," and held that a civil action to recover such a "tax" was constitutionally barred by a prior conviction based upon the same transaction. 


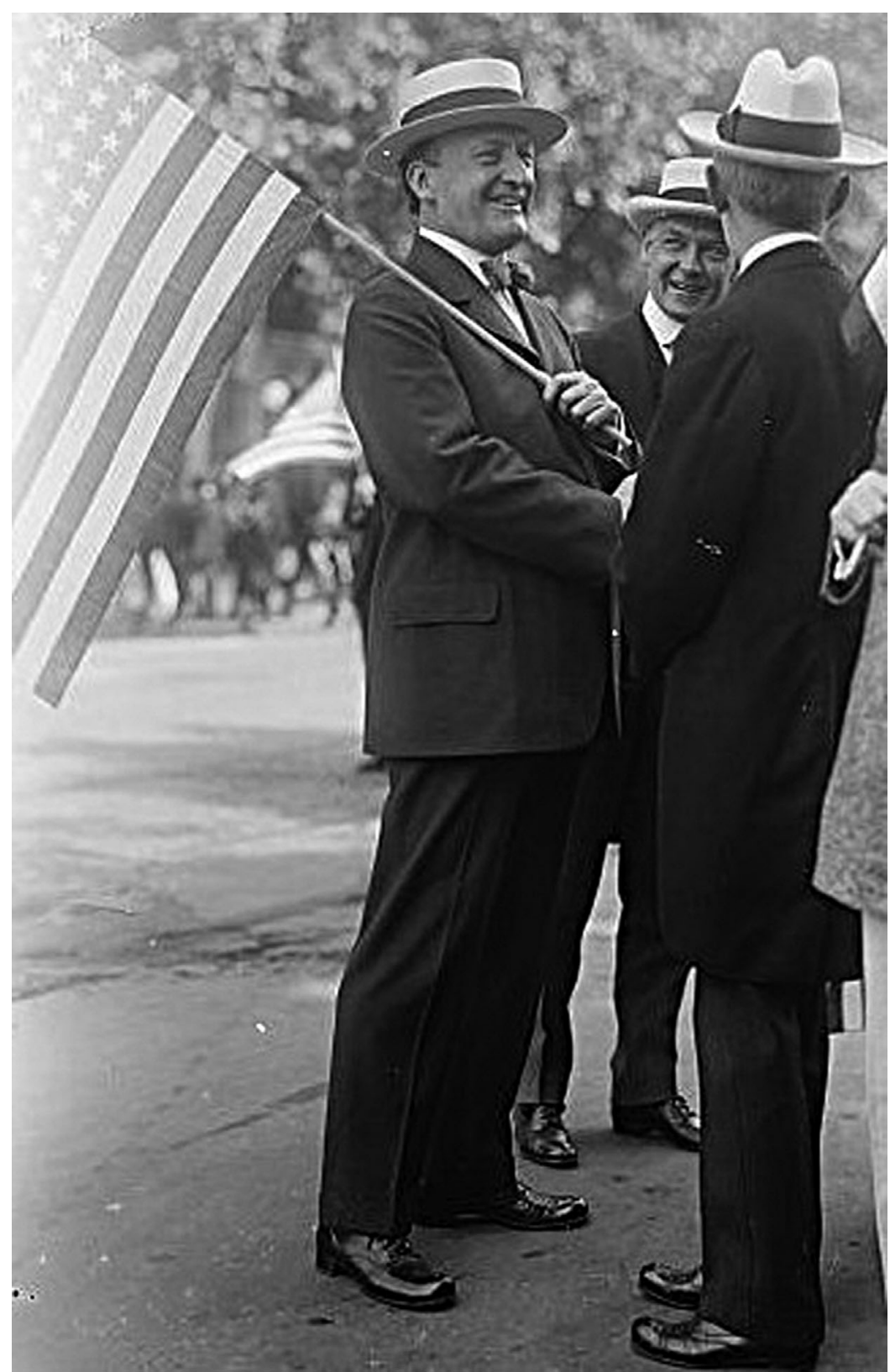

Surprisingly, the notoriously cantankerous and disagreeable Justice James Clark McReynolds (above) was the Justice who most frequently acquiesced in the majority's opinion after dissenting or passing at the conference vote.

At the conference, however, Holmes, Stone, and probably Brandeis disagreed. ${ }^{69}$ Patton $v$. United States $^{70}$ confirmed that the jury trial guaranteed to those accused of crime required the unanimous verdict of a panel of twelve jurors, but that this right could be waived by the defendant. The published decision registered no dissent, with Holmes, Brandeis, and Stone concurring in the result. At the conference, however, Butler had disagreed with his colleagues. ${ }^{71}$ And in Alford $v$. United States, ${ }^{72}$ a unanimous Court vigorously confirmed the right of the accused's counsel to attempt to discredit a hostile witness on 
cross-examination. At the conference, however, McReynolds had voted to dismiss the defendant's appeal.

McReynolds again passed in conference $^{73}$ but ultimately made a unanimous Court in United States v. Lefkowitz. There the Court reversed a conviction where police, acting pursuant to an arrest warrant for violation of the liquor laws, arrested defendants at their place of business and proceeded to search desks and filing cabinets in the office, and to seize various papers for use against the defendants at trial. The Justices held that the papers in question were not in plain view and that the search of the desks and cabinets therefore was not a lawful search incident to arrest. ${ }^{74}$ It appears that Stone may also have had doubts about his position in conference: Butler records a question mark next to Stone's vote. A clue to the reasons for Stone's ambivalence might be found in the remarks of McReynolds. Butler records McReynolds as saying "Murder-Pistol. Narrow space," which suggests that he may have believed that the search of the desks and cabinets was justified as a means of insuring the safety of the officers. The other Justices do not appear to have shared this hesitation. Butler records Hughes as saying "Search attending arrest may not be exploratory"; Van Devanter as "Is the same. Papers from person"; and Brandeis as "Papers even persons ought to be protected." 75 Finally, the published decision in Gebardi v. United States $^{76}$ was unanimous, with Cardozo concurring in the result, but at the conference both Cardozo and Brandeis cast dissenting votes. There the Court reversed the conviction of a man and woman for conspiracy to violate the Mann Act, which prohibited the interstate transportation of a woman for an immoral purpose. The couple admittedly had taken an interstate journey whose itinerary included frequent stops for fornication. Yet the Court held that the transported woman was capable neither of committing nor of conspiring to commit any offense under the
Act. As the man had conspired with no one else for the forbidden transportation, his conspiracy conviction had to be vacated as well. As Hughes put it at conference, "Woman n.g. [not guilty] of such offense. She merely consents.... No conspiracy.,"77

\section{Non-Unanimous Decisions with No Vote Changes}

Some of the most important non-unanimous decisions of the early Hughes Court were decided with no vote changes between the conference vote and the final vote on the merits. This was the case in three major cases upholding state power to regulate economic matters, in each of which Van Devanter, McReynolds, Sutherland, and Butler cast dissenting votes. The first was O'Gorman \& Young, Inc. v. Hartford Fire Ins. Co. ${ }^{78}$ which upheld against a Due Process challenge state regulation of the commission rates charged by agents selling fire insurance policies. The second was Home Bldg. \& Loan Assn. v. Blaisdell, ${ }^{79}$ a Contracts Clause landmark upholding Minnesota's mortgage moratorium law as an emergency measure. Butler's exasperation with his colleagues suffuses his account of Hughes's presentation to the conference. Virtually every mention of the term "emergency" is placed in scare quotes. The native Minnesotan records Hughes's statement as marked by "Much exordium." Hughes apparently referenced the "preamble" to the statute, which declared that the extremely distressed financial conditions in Minnesota had generated a mortgage foreclosure crisis that constituted a "public economic emergency"; 80 "Holt's picture," presumably a reference to the description of the financial condition of the housing market provided by Justice Andrew Holt's opinion for the Minnesota Supreme Court upholding the act; "Olson's statement," referring to Justice Ingerval Olsen's concurring opinion in the case, in which he likened the nationwide and worldwide financial crisis to a natural disaster such as a flood or 


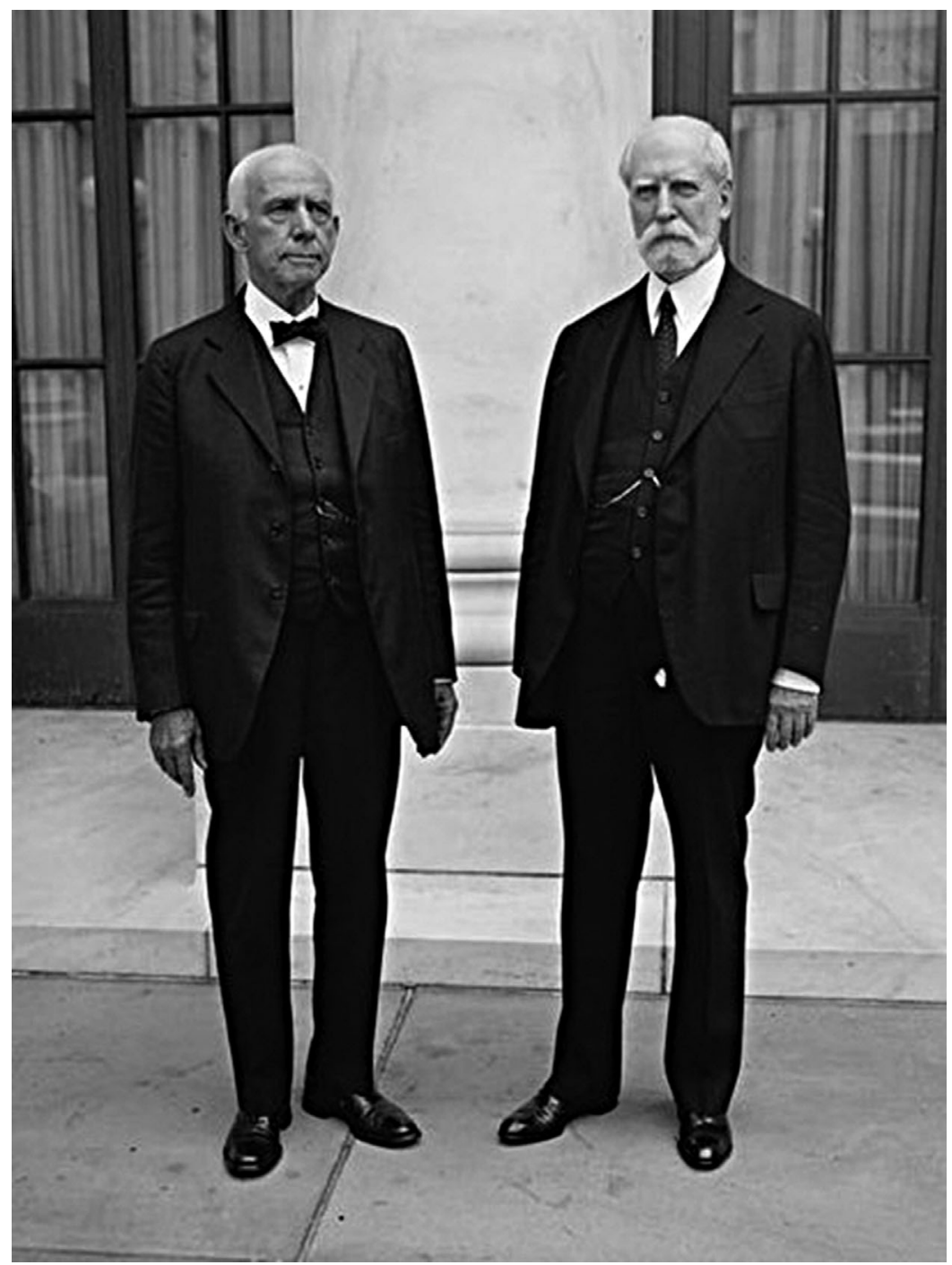

Justice Willis Van Devanter suffered from writer's block and by the 1931 and 1932 Terms his production had slowed down to one opinion a year. The docket books show instances when Chief Justice Hughes (right) would reassign an opinion because Van Devanter (left) couldn't finish it. They also reveal other examples of cases initially assigned to one Justice later being transferred to another.

earthquake; 82 "Atty Gen," referring to Minnesota Attorney General Henry Benson's statement of general economic conditions in the state in his argument before the Court; 83 and "mobs etc," referring to the "serious breaches of the peace" in the state that the Attorney General had mentioned at oral argument. "A4 "All" of this, Hughes declared, 'shows 'Emergency.' 'Emergency' does not create power-no provision can be suspended by "emergency." Hughes also cited the "Manigault case 199 U.S.," a reference to the 1905 decision of Manigault v. Springs, ${ }^{85}$ which the Chief Justice would cite in his majority opinion as standing for the proposition that " $[\mathrm{t}]$ he economic interests of the state may justify the exercise of its continuing and dominant protective power notwithstanding interference with contracts." 86 
The third such case was Nebbia v. New York, ${ }^{87}$ which upheld the state's regulation of the price of milk and in the process retired the category of "business affected with a public interest" from the Court's due process jurisprudence. Interestingly, the remarks of Hughes at the Nebbia conference suggest that initially he advocated an opinion that would have been narrower and less sweeping than the one ultimately produced by Roberts. Butler records Hughes as remarking "“Common calling.' Distinguishing Ice CaseWolf Case." ${ }^{\prime 8}$ The "Ice Case" was the 1932 decision of New State Ice v. Liebmann, in which a 6-2 Court had invalidated an Oklahoma statute conditioning issuance of license to manufacture, sell, or distribute ice on the applicant's successful showing that existing licensed facilities in the community were inadequate to meet the public's needs, on the ground that the ice business was not "affected with a public interest." 89 The "Wolf Case" was the 1923 decision in Wolff Packing v. Kansas Court of Industrial Relations, in which the Court had held that a meatpacking concern could not be subjected to a mandatory system of compulsory arbitration of labor disputes because it was doubtful that it was "affected with a public interest," and even if it was, it was not the sort of business affected with a public interest that could be compelled by the state to continue its operations. ${ }^{90}$ Hughes continued, "Milk business regulated in NY. 'listed regulations.' 'Clear as sunshine." 91 These remarks suggest that Hughes agreed with New York's lawyers that it was not necessary to jettison the category of businesses "affected with a public interest" in order to uphold the state's scheme of price regulation. ${ }^{92}$ The New York statute did not constitute a barrier to entry into a common calling as the Oklahoma regulation of the ice business had. And it did not seek to compel continuity of operations as the Kansas Industrial Court Act at issue in Wolff Packing had. It seems that Hughes regarded the milk business as sufficiently "affected with a public interest" to support the system of price regulation to which New York had subjected it.

A similar pattern can be observed in several cases involving civil rights and civil liberties. Consider first Powell v. Alabama, ${ }^{93}$ the famous case involving the trial of the "Scottsboro Boys," several young AfricanAmericans charged with raping two white girls on a train in Alabama. ${ }^{94}$ There the Justices held that the Fourteenth Amendment's Due Process Clause entitled indigent defendants in a capital case to effective, court-appointed counsel. The trial judge had appointed the entire local bar rather than a specific attorney to represent the defendants, which resulted in a lawyer from outside the state with no criminal defense experience in Alabama representing the defendants. The majority held that this procedure was plainly inadequate. The vote both at conference and in the published decision was 7-2, with McReynolds and Butler dissenting. ${ }^{95}$ Butler records that at the conference Hughes stated, "(a) 'Show of force,"” apparently referring to the large presence of intimidating local whites at the trial. Butler here interjects in brackets, apparently capturing his own thoughts that were not necessarily voiced, "But did not that make for a 'fair trial.' Did not hold "mob domination." "Here Hughes continued, "(b) Under circumstances court failed in its duty in appointing counsel. (c) Trial a 'farce'. (d) Need not go equal protection in respect of negroes on jury." Van Devanter spoke next, saying "Not due process. Does not find 'mob domination'went on sole ground of 'lack of opportunity' to get counsel of their own choice and to confer re." McReynolds said "Not void trial," and Brandeis stated, "Agree with V also with C.J. Absence of negroes on jury and circumstances." The last Justice whose remarks Butler recorded was Sutherland, who ultimately wrote the majority opinion. "States generally provide counsel-part of due process," Sutherland maintained. 
"To appoint all is a farce. Denial of counsel." 96

In Sgro v. United States, ${ }^{97}$ a federal officer had obtained a warrant to search the premises of the accused for intoxicating liquors in early July. Under the National Prohibition Act, such warrants expired ten days after their issuance. The officer did not search the premises until late July, but before doing so he returned to the magistrate and had the warrant re-dated and reissued based upon the original affidavit. The accused was convicted based on evidence obtained during the subsequent search. Over the dissents of Stone and Cardozo, the Court held that the warrant had been invalid - once the original warrant had expired, a new warrant had to be issued based on a finding of probable cause existing at that time. The vote at conference was also 7-2 and with the same line-up, ${ }^{98}$ but some intracurial developments between the initial vote and the announcement of the decision shed light on McReynolds's separate concurrence. After the October 15 conference at which the initial vote was taken, the case was assigned to McReynolds. However, at the November 12 conference, held after McReynolds's opinion had been circulated, the Justices discussed a memorandum on the case that had been prepared by the Chief Justice. ${ }^{99}$ From the published opinions it appears that McReynolds favored a "definite rule" that "no search warrant should issue upon an affidavit more than ten days old."100 Hughes, by contrast, argued that, though the statute did not "fix the time within which proof of probable cause must be taken" by the magistrate, "the proof must be of facts so closely related to the time of the issue of the warrant as to justify a finding of probable cause at that time." Whether the proof met this test, Hughes maintained, "must be determined by the circumstances of each case." 101 Van Devanter remarked that he "Thought memo an improvement," but Butler records that "C.J.'s memo not accepted by McR. . . Supported his op.- - aff. and state why (?) - Leaves every case on its own bottom." 102 The conference then voted to accept the Hughes memo. Both Butler and Roberts record the vote as 5-3, with McReynolds, Stone, and Cardozo dissenting, and Butler passing. ${ }^{103}$ The case was then reassigned to Hughes, ${ }^{104}$ who produced the majority opinion. ${ }^{105}$

Two landmark First Amendment cases and a naturalization case round out this category of early Hughes Court decisions. In Stromberg v. California, ${ }^{106}$ which invalidated California's statute prohibiting display of a red flag as "a symbol or emblem of opposition to organized government," McReynolds and Butler were the only dissenters both at conference and in the published decision. All Four Horsemen dissented both in conference and from the published opinion in Near $v$. Minnesota, ${ }^{107}$ which invalidated as an unconstitutional prior restraint a statute authorizing suits to enjoin newspaper publishers of "malicious, scandalous and defamatory" material from future publication on pain of contempt. United States v. McIntosh, ${ }^{108}$ which upheld the denial of naturalization to a Canadian citizen who declined to take the oath of allegiance without qualification, was also 5-4 both at conference and in the published decision. This time, however, the Four Horsemen and Roberts were in the majority, with Hughes, Holmes, Brandeis, and Stone in dissent.

\section{Vote Changes in Non-Unanimous Decisions}

Perhaps the most prominent early Hughes Court decision in this category is one about which the internal evidence for its inclusion is conflicting. In the 1927 case of Nixon v. Herndon, ${ }^{109}$ the Court had unanimously invalidated a Texas statute excluding African Americans from participation in the state Democratic party's primary elections. The 1932 case of Nixon v. Condon ${ }^{110}$ invalidated a revised version of the "white primary" concocted in the wake of Herndon. 
Rather than the state directly specifying the eligibility criteria for participation in primary elections, the Texas legislature authorized the political parties to do so. The Democratic party in turn promulgated qualifications that excluded African Americans. The central question was whether the action of the legislature in authorizing the parties to promulgate qualifications under which African-American voters would be excluded from voting constituted state action triggering application of the Fourteenth and Fifteenth Amendments. The intracurial proceedings produced divergent accounts in the docket books. Stone records the conference vote as identical with the final vote of 5-4, with the Four Horsemen dissenting, but he does not date the conference. ${ }^{111}$ Roberts's account suggests that a vote taken at the January 9 conference may initially have been unanimous to reverse the lower court decision upholding the arrangement, with Brandeis not voting. But the vote notations suggesting this are then crossed out, and the case was "Restored to docket for reargument at a time to be later fixed by the Court." The case was reargued March 15, and Roberts records that on March 19 the Court voted 5-4 to reverse. ${ }^{112}$ Butler, by contrast, records the initial conference as taking place on January 16. At this conference, Butler records Hughes as saying, "Party control important. Regulation not enough - 15[th] Am[endment] no[t] appl. to primary. 'Much' then came out as holding "state action." Hughes concluded, "No state action." To this Holmes replied, "That attitude is form of words." Van Devanter agreed with Hughes, McReynolds voted to affirm, and Brandeis maintained "This is state action." Sutherland is recorded as " $1+$," that is, agreeing with Hughes with some qualification. Butler agreed with Hughes, and Roberts and Cardozo both agreed with Holmes. The conference vote appears to have been equally divided with Holmes, Brandeis, Roberts, and Stone arrayed against the Four Horsemen, and the
Chief Justice not voting. The case was restored to the docket on January 18, and, after the March 15 reargument, the Court met again to discuss the case on March 19. Here again Hughes is recorded as saying, "Reg. by state of primaries not enough." It appears that the vote may again have been equally divided, with Cardozo taking the position previously adopted by the now-retired Holmes. Butler never recorded a vote in the case for Hughes, and Butler's record of Hughes's comments at the March $19^{\text {th }}$ conference does not suggest a vote to reverse. It may be that the docket book entries made by Stone and Roberts were recorded after that conference, when the Chief announced his conclusion. The decision was not announced until May 2, so it appears that the Chief Justice may have taken some time in finally seeing his way clear to joining the majority. ${ }^{113}$

In Funk v. United States, ${ }^{114}$ the Court held that in a federal criminal trial the wife of the accused is a competent witness on his behalf. The final vote was 7-2, with McReynolds and Butler dissenting, and Cardozo concurring in the result. At the conference, however, Van Devanter and Brandeis also had cast dissenting votes. In United States $v$. Murdock, ${ }^{115}$ the Court held, over the dissents of Stone and Cardozo, that it was reversible error for the trial judge to inform the jury of his view that the accused was guilty beyond a reasonable doubt. The conference vote was 6-2, with McReynolds passing. ${ }^{116}$ And, in Sorrells v. United States, ${ }^{117}$ the Court reversed a conviction on the grounds that the Prohibition Act had not been intended to apply to circumstances in which an otherwise innocent defendant had been lured into a sale of liquor at the instigation of a Prohibition agent - and evidence of entrapment had not been permitted to go to the jury. The final vote was 5-4, with McReynolds, Brandeis, Stone, and Roberts dissenting, but this was preceded by a good deal of movement behind the scenes. At the conference the vote was 5-2, with McReynolds and Roberts in the 
minority, and Stone and Cardozo passing. Before the decision was announced Cardozo would join the majority, Stone would cast his lot with the dissenters, and Brandeis would defect from the majority to the dissent.

Two important immigration and naturalization decisions also witnessed vote shifts between the conference vote and the final vote on the merits. In United States $v$. Bland, ${ }^{118}$ the Court upheld denial of naturalization to a Canadian citizen who declined to take the oath of allegiance without qualification. The final vote was 5-4, with Hughes, Holmes, Brandeis, and Stone dissenting. At the conference, however, the vote had been 63 , with Stone in the majority. And in Hansen v. Haff, ${ }^{119}$ the Court rejected an attempt to deport a Danish woman who returned to the United States with the intention of continuing to engage in illicit sexual relations with a married man, refusing to characterize her entry as one for an "immoral purpose." Butler authored a lone dissent from the published decision, but at the conference he had been joined in opposition by Brandeis.

Finally, in United States v. Limehouse, ${ }^{120}$ the Court upheld the conviction of a man for mailing "filthy" letters containing language Brandeis's majority opinion described as "coarse, vulgar, disgusting, indecent, unquestionably filthy" and "foul."121 The published opinion notes a lone dissent without opinion by McReynolds, with Cardozo taking no part. At the conference, however, Stone records that Sutherland and Butler were also in the minority. ${ }^{122}$ Butler records that the vote was initially $4-4$, but that Roberts "changed to get majority," making it 5-3. Butler further records Hughes as saying of Mr. Limehouse's missives, "Yes filthy. Foul."123

In the domain of economic regulation, two important state police power cases saw changes in alignments between the conference vote and the final vote on the merits. As mentioned above, New State Ice Co. v. Liebmann ${ }^{124}$ struck down a statute that required those seeking a license to manufacture, sell, or distribute ice to demonstrate that existing licensed facilities in the community were inadequate to meet the public's needs. The final vote was 6-2, with Cardozo taking no part and Stone joining Brandeis's nowfamous dissent. At the conference, however, the vote was 6-1, with Stone passing. It is clear, however, that Stone was already leaning toward dissent. Butler records him at conference as saying, "Can't say a priori state can't do this." 125 McReynolds, who had narrower notions of federal jurisdiction than did most of his colleagues, ${ }^{126}$ stated, "Fed court doesn't deal with this." In presenting the case, Hughes stated, "No satisfactory criteria of 'affected with a public interest.' Differs in relation of things. Test: 'inherent in liberty' right to engage in ordinary occupation." "127 These remarks indicate that Hughes objected to the fact that the statute created a barrier to entry for a common callingsomething to which he had objected as an Associate Justice, ${ }^{128}$ and to which he would again object later in the decade. ${ }^{129}$ Roberts, who would vote with Hughes in these later cases as well, expressed his agreement with the Chief Justice. Butler records Hughes as making one other remark: "'Cotton Ginning' dif-." Butler likewise has Sutherland agreeing that "Cotton Gin is different." 130 The reference here was to a recent Tenth Circuit decision sustaining a statute treating the business of cotton ginning as affected with a public interest, ${ }^{131}$ which the appellant in Liebmann invoked in support of the constitutionality of Oklahoma's similar treatment of the ice business. ${ }^{132}$ In his opinion for the majority, Sutherland explained that cotton gins were affected with a public interest because they held a de facto monopoly in the provision of a necessary service, and therefore were in a position to subject growers to "exorbitant charges and arbitrary control." "133 By contrast, Sutherland argued, the business of ice making was not a practical monopoly, and therefore could not be 
regulated as a business affected with a public interest. ${ }^{134}$

In Stephenson v. Binford, ${ }^{135}$ the Court upheld a regulation issued by the Texas Railroad Commission requiring private contract carriers to charge certain minimum rates for transport. The regulation had been imposed in order to protect the state's rail carriers from the destructive competition of private carriers. The Court did not consider whether the competitive threat alone justified the regulation, nor did the Court reach the issue of whether the private carriers conducted a business affected with a public interest. Instead, Sutherland's opinion for the majority upheld the regulation on the grounds that "the highways of the state are public property; that their primary and preferred use is for private purposes; and that their use for purposes of gain is special and extraordinary, which, generally at least, the legislature may prohibit or condition as it sees fit."136 The impression that the Justices were casting about for a rationale upon which the order might be sustained is confirmed by Butler's account of the conference. Hughes opened the conference by asserting, inter alia, "Price fixing is good." Van Devanter passed, at which point McReynolds opined that "State should regulate. But can't fix prices." Sutherland told his colleagues, "Want to sustain. Not a business impressed with a public interest. Might be sustained as a [illegible] measure." 137 After this discussion, the conference vote yielded a 7-2 majority in favor of upholding the order, with McReynolds and Butler dissenting. ${ }^{138}$ Before the judgment was announced, however, McReynolds abandoned his friend and acquiesced in the opinion of the majority. In the end, Butler dissented alone. ${ }^{139}$

Similar dynamics were at play in the divisive domain of intergovernmental tax immunity. In Educational Films Corp. v. Ward, ${ }^{140}$ a 6-3 majority held that a state tax that included as income royalties received from copyrights obtained under federal law did not infringe the constitutional tax immunity of the federal government. The conference vote was 5-4, with all Four Horsemen in the minority, but in the end McReynolds acquiesced in Stone's majority opinion. In Indian Motorcycle Co. v. United States, ${ }^{141}$ only Brandeis and Stone dissented from the holding that a sale of a motorcycle to a municipal corporation of Massachusetts could not be subjected to federal taxation. Holmes had voted with them at the conference, but in the published decision he dutifully engaged in his common practice of quasi-acquiescence, noting that he regarded the decision in Panhandle Oil Co. v. Knox ${ }^{142}$ "as controlling in principle and upon that ground acquiesces in this decision."143

Burnet v. Coronado Oil \& Gas Co. ${ }^{144}$ involved land that the federal government had granted to the state of Oklahoma for the purpose of supporting common schools. The state in turn leased the land to the company for the purpose of extraction of oil and gas. A portion of the gross production from the site was reserved to the state, with the balance being sold by the company. The Court held that the company was an instrumentality of the state for purposes of generating revenue to support the public schools, and that the income from sales of the oil and gas produced at the site was constitutionally immune from federal taxation. In doing so, the majority felt bound by the precedent of Gillespie v. Oklahoma, ${ }^{145}$ and McReynolds's opinion for the Court pledged to construe that precedent strictly. ${ }^{146}$ This was not enough to satisfy the dissenters, who called for Gillespie to be overruled. ${ }^{147}$ It was in Burnet that Brandeis famously wrote that "Stare decisis is usually the wise policy, because, in most matters, it is more important that the applicable rule of law be settled than that it be settled right... But in cases involving the Federal Constitution, where correction through legislative action is practically impossible ... this court should refuse to follow an earlier constitutional decision which it deems erroneous." 148 
Brandeis must have been particularly disappointed by the result in Burnet, because there was a time when it seemed that a majority was within his grasp. The original argument was held on January 15, 1932, ${ }^{149}$ and the conference was held the following day. The conference vote was 4-4: the Four Horsemen voted to invalidate the tax as applied, while Hughes, Brandeis, Stone, and Roberts voted to uphold application of the tax. ${ }^{150}$ It is likely that Holmes would have been inclined to join with Brandeis, et al., but he had resigned from the Court just three days before the argument. ${ }^{151}$ In his presentation to the conference, Hughes opined that "Oil Co. not state instrumentality." $" 152$ But because Hughes was unable to persuade any of the Horsemen to his views, the case was held over for further consideration, and passed over at the February 13 conference. ${ }^{153}$ On February 15, President Hoover nominated Cardozo to replace Holmes. Cardozo's rapid confirmation seemed assured, ${ }^{154}$ and there was probably little doubt in the minds of his future colleagues which way he would vote in Burnet. At the February 20 conference, the Justices restored the case to the docket for reargument, ${ }^{155}$ and Cardozo took his seat on March 2. The second argument was held March 16, ${ }^{156}$ and on March 19 the Justices again met to vote on the case. As anticipated, Cardozo voted with Brandeis. In the meantime, however, the Chief Justice had slipped away. Apparently lured by the call of stare decisis, Hughes defected from what would have been a majority to overrule Gillespie to create instead a majority to preserve and follow it. ${ }^{157}$ It may well have been these frustrating events behind the scenes that inspired Brandeis to select this particular occasion to deliver his celebrated remarks on the role of precedent in constitutional adjudication. $^{158}$

Consider finally Crowell v. Benson, ${ }^{159}$ a 1932 decision upholding and construing the Longshoremen and Harbor Workers Act of 1927, and a landmark in the development of administrative law. At the conference on October 31, 1931, the vote was 8-1 to affirm, with only Brandeis dissenting. Between the time of the conference vote and the announcement of the final decision, there were two important developments relative to the case. First, Holmes retired the following January, shrinking the majority to seven Justices, and Cardozo was not confirmed until after the opinion had been delivered. Second, Stone and Roberts defected from the majority to join Brandeis in dissent. The result was the 5-3 division that appears in the published report of the decision. ${ }^{160}$

\section{Reassignments}

It is well known that Van Devanter was the Hughes Court's least productive writer of opinions. ${ }^{161}$ In 1960, Professor Arthur Schlesinger, Jr. reported that:

In conference, Van Devanter's lucidity, knowledge, and sweetness of manner commanded the respectful attention even of brethren who detested his conclusions. But at his desk, an awful paralysis overtook him; and he could only rarely get his views down on paper. By 1931 and 1932 his production had slowed down to one opinion a year. Sometimes Hughes would take cases back from him. "You are overworked," he would say with ambiguous and sardonic courtesy. "Let me relieve you of some of your burden.",162

The docket books enable us to verify the substance of this claim, and to identify other instances in which a case initially assigned to one Justice was later transferred to another. During the 1930 Term, Van Devanter gave up three cases, one each to Holmes, ${ }^{163}$ Roberts, ${ }^{164}$ and McReynolds. ${ }^{165}$ The following year, Van Devanter relinquished two cases to Hughes, ${ }^{166}$ while Stone accepted one 
from the Chief Justice ${ }^{167}$ and Cardozo took a case from McReynolds ${ }^{168}$ in which the latter ultimately dissented. ${ }^{169}$ For the 1932 Term, Van Devanter handed off an opinion each to Roberts ${ }^{170}$ and Hughes, ${ }^{171}$ and Roberts relieved Stone of a case ${ }^{172}$ in which the latter ultimately dissented. ${ }^{173}$ As discussed above, Hughes assumed control of the opinion in Sgro v. United States after the conference expressed its preference for his memorandum over McReynolds's draft opinion. ${ }^{174}$ And during the 1933 Term, Van Devanter released opinions to Stone ${ }^{175}$ and Cardozo, ${ }^{176}$ while accepting one from McReynolds. ${ }^{177}$ Most of the reassignments that Hughes ordered during the early years of his tenure as Chief Justice thus resulted either from changes in the vote after the conference, or from Van Devanter's inability to produce an opinion in a case with which he had been entrusted.

\section{Conclusion}

In addition to the information that they provide about the Court's deliberations in particular cases, the docket books of the early Hughes Court Justices teach us some larger lessons. First, they confirm Arthur Schlesinger, Jr.'s claim that Hughes occasionally was obliged to relieve Van Devanter of his literary burdens, and they show that the few other instances in which Hughes reassigned cases typically involved a post-conference voting shift.

Second, the docket books teach us that McReynolds's published record in cases involving political economy would lead one to believe that he was more amenable to regulation and taxation than his conference conduct would indicate. Though he ultimately joined the majorities in Federal Trade Commission v. R.F. Keppel \& Bro., United States v. Louisiana, Stephenson v. Binford, Fox Film Corp. v. Doyal, and Educational Films Corp. v. Ward, he cast a dissenting vote in each of these cases at conference. In addition, though he ultimately voted to uphold government regulation in FTC v. Algoma Lumber Co., at the conference vote he passed. The published decisions can also be misleading concerning McReynolds's views in cases involving civil rights and civil liberties. Though he ultimately joined majorities favoring such claims in many cases, at conference he passed in United States $v$. Lefkowitz and United States v. Murdock. And assuming that Butler's notes on the conference discussion in Nixon v. Condon faithfully record the Chief Justice's remarks, Hughes was less inclined to strong protections of voting rights than his vote in the published opinion would suggest.

The civil liberties views of Stone and Cardozo also are illuminated by the docket book records. These two Justices publicly dissented from a number of decisions reversing criminal convictions ${ }^{178}$-indeed, Stone complained that Butler was soft on crime $^{179}$ - but their conference votes reveal them to be even less favorably inclined toward claims of the accused than their published votes would suggest. Cardozo joined the majority in Gebardi v. United States, but at conference he had dissented. Stone ultimately joined the majorities in Sorrells v. United States and United States $v$. LaFranca, but at conference he passed in the former and dissented in the latter. And, though Stone ultimately joined the dissenters in United States v. Bland, at the conference he voted with the majority.

The docket books also reveal considerable fluidity between the initial conference vote and the final vote on the merits among the Justices of the early Hughes Court. First, there were nine instances of defection in major cases. Stone was responsible for six of these, departing from a conference vote with the majority in Bland and Crowell, and from a passing conference vote in Sorrells, Liggett, Rock Island, and Liebmann, though Butler's conference notes indicate that Stone was already inclined to join Brandeis in his 
Liebmann dissent. Holmes departed from a passing conference vote in Rock Island, Brandeis ultimately abandoned his vote with the Sorrells conference majority, and Roberts joined in Stone's defection from the Crowell conference majority. Thus, four of these defections were of the strong variety, and five of the weak variety. Second, there also were shifts in voting that created majorities where none had formed at the conference. Hughes was responsible for two such instances, shifting his vote to form new 5-4 majorities for positions that he had initially opposed in conference in Nixon $v$. Condon and Burnet. Similarly, Roberts shifted his initial conference vote in Limehouse in order to transform a 4-4 deadlock into a majority for affirmance. Third, though Holmes voted with the dissenters at the Indian Motorcycle conference, he ultimately adhered to his custom of quasi-acquiescence.

The most common form of vote fluidity on the early Hughes Court, however, was acquiescence. Of the thirty-four unanimous decisions discussed here, twenty-one $(61.8 \%)$ also were unanimous at conference, but thirteen $(38.2 \%)$ were not. This observation is consistent with earlier studies finding that conformity voting is the most common form of vote fluidity. ${ }^{180}$ The frequency with which each of the Justices acquiesced in the views of the majority is worthy of note. The notoriously cantankerous and disagreeable Justice McReynolds was actually the member of the Court most likely to acquiesce in a decision in order to produce unanimity. Of the thirteen unanimous decisions examined here that were not unanimous at conference, McReynolds acquiesced in seven (53.8\%). By contrast, Sutherland did so in three $(23.1 \%)$, Brandeis and Stone in two (15.4\%) each, and Holmes, Van Devanter, Butler, and Cardozo in one $(7.7 \%)$ each. Of these eighteen instances of acquiescence, eleven were of the strong variety, six of the weak variety, and the character of the last cannot be determined with confidence. ${ }^{181}$
With respect to cases that did not produce unanimity, McReynolds and Brandeis each acquiesced in three, while Van Devanter, Sutherland, Butler, and Cardozo each acquiesced in one. Of these ten instances of acquiescence, eight were of the strong variety, and two were of the weak sort. ${ }^{182}$ Thus, of these twenty-eight instances of acquiescence in major cases decided by the early Hughes Court, nineteen were of the strong variety, eight of the weak variety, and the character of one cannot be determined with confidence. McReynolds alone was responsible for $35.7 \%$ of these instances of acquiescence, recording ten in all. By contrast, Brandeis accounted for five $(17.9 \%)$, Sutherland for four (14.3\%), and Van Devanter, Butler, Stone, and Cardozo for two $(7.1 \%)$ each. Expressed as a percentage of acquiescences per conference vote in which he participated, McReynolds acquiesced in $18.2 \%$ of such cases, Brandeis in $8.5 \%$, Sutherland in $6.8 \%$, and Van Devanter, Butler, and Stone in $3.4 \%$ each. ${ }^{183}$ Of all of the early Hughes Court Justices, the only Justices who did not acquiesce in any of the cases examined here were the two who sat at the Court's center of gravity: Hughes and Roberts. The fact that McReynolds was the early Hughes Court Justice most likely to acquiesce in major decisions echoes Professor Saul Brenner's finding that on the Vinson Court "extreme justices [were] most likely to be closer to the mean at the final vote than at the original vote," because "extreme justices are likely to lose more often at the original vote." 184

The fact that two of the most senior Justices-McReynolds and Brandeis-were those who most frequently acquiesced in the conference majority's judgment in major cases also indicates that newcomers to the early Hughes Court did not experience the kind of freshman effect with respect to voting fluidity that some scholars have found on other Courts. Indeed, the only Justices to acquiesce in fewer major cases than Cardozo were Hughes and Roberts, and Roberts acquiesced in none. Moreover, both Roberts 
and Cardozo would continue to acquiesce in major cases at comparable or higher rates later into their tenures on the Court. ${ }^{185}$ This finding would appear to be in tension with Paul Freund's recollection that Cardozo often changed his vote between the conference vote and the final vote on the merits during the 1932 Term. However, Freund reported that, "As far as I could make out, [Cardozo's] disagreements [with the majority in conference] - this being his first full term on the Court-derived from the fact that in New York he had been accustomed to a rather different set of procedural rules and substantive rules intermeshed with procedure, so that some things which were decided one way in the federal courts would have been decided differently in New York," and that this is what may have accounted for the Justice's allegedly frequent changes of vote between the conference and the final vote on the merits. ${ }^{186}$ This suggests the possibility that Cardozo may have exhibited greater freshman vote fluidity in less salient cases not examined here. $^{187}$

The Justices of the early Hughes Court, seven of whom were holdovers from the Taft Court, thus carried forward the practices so carefully cultivated by Hughes's predecessor as Chief Justice. Taft is famous for his "consuming ambition" to "mass the Court"to build unanimity so as to give "weight and solidity" to its decisions. ${ }^{188}$ The Taft Court achieved unanimity in a remarkable percentage of its cases. For the 1921-1928 Terms, $84 \%$ of the Court's published opinions were unanimous; ${ }^{189}$ taking into account all of its decisions for the entirety of Taft's tenure, the unanimity rate was $91.4 \% .{ }^{190}$ This rate of unanimity was in line with the rates achieved by the White Court, on which Holmes, Van Devanter, McReynolds, Brandeis, and Hughes each had served, ${ }^{191}$ and the attitudes formed under White and his predecessors appear to have contributed to the persistence of this phenomenon. Taft discouraged dissents, believing that most of them were displays of egotism that weakened the Court's prestige and contributed little of value. ${ }^{192}$ As a consequence, he worked hard to minimize disagreement, often sacrificing the expression of his own personal views. ${ }^{193}$ Van Devanter shared Taft's distaste for public displays of discord, and strongly lobbied his colleagues to suppress their dissenting views. ${ }^{194}$ Butler similarly regarded dissents as exercises of "vanity" that "seldom aid us in the right development or statement of the law," and instead "often do harm."195 He therefore commonly "acquiesce[d] for the sake of harmony \& the Court."196 McReynolds and Sutherland expressed similar views, and suppressed dissenting opinions accordingly. ${ }^{197}$ Even the "great dissenters," Holmes and Brandeis, believed that dissents should be aired sparingly, and often "shut up," as Holmes liked to put it, when their views departed from those of their colleagues. $^{198}$

Like Taft, Hughes "sought to present a united Court to the public,"199 frequently suppressing his own views for the sake of unanimity. As he wrote on his return of one of Stone's draft opinions, "I choke a little at swallowing your analysis, still I do not think it would serve any useful purpose to expose my views." 200 In his efforts "to find common ground upon which all could stand," Hughes "was willing to modify his own opinions to hold or increase his majority; and if this meant he had to put in some disconnected thoughts or sentences, in they went." ${ }^{, 201}$ And while Hughes dissented at a higher rate as Chief Justice than had White or Taft, he did so at a much lower rate than would Stone, Fred Vinson, or Earl Warren. ${ }^{202}$

A variety of factors may have contributed to what Dean Robert Post calls this "norm of acquiescence." ${ }^{203}$ Here I wish to highlight just a few. First, the literature of the period illustrates among the bench and bar a widely held aversion to dissents as excessively selfregarding, and as weakening the force of judicial decisions by unsettling the law. ${ }^{204}$ 
This conviction found expression in Canon 19 of the American Bar Association's Canons of Judicial Ethics, which exhorted judges not to "yield to pride of opinion or value more highly his individual reputation than that of the court to which he should be loyal. Except in cases of conscientious difference of opinion on fundamental principle, dissenting opinions should be discouraged in courts of last resort." Instead, "judges constituting a court of last resort" were admonished to "use effort and self-restraint to promote solidarity of conclusion and the consequent influence of judicial decision." 205 Taft was the chair of the committee that drafted the Canons, and Sutherland was a committee member before his appointment to the Court. ${ }^{206}$ Second, the norm of acquiescence promoted a collegiality and reciprocity among the Justices that smoothed over potential conflicts and avoided alienating colleagues whose support one might need in future cases. ${ }^{207}$ Third, during this period nearly all of the Justices had only one clerk rather than the four that Justices typically have today, and most of the Justices wrote their own opinions. ${ }^{208}$ With such comparatively limited resources at their disposal, the cost of preparing a dissenting opinion was considerably higher. ${ }^{209}$

The unanimity rates of the early Hughes Court were remarkably similar to those of the White and Taft Courts. For the 1930 Term the rate was $89.2 \%$; for the 1931 Term it was $82.7 \%$; for the 1932 Term it was $83.9 \%$; and for the 1933 Term it was $83.5 \%$. Even during the height of the Court's encounter with the New Deal, unanimity rates remained robust: $85.9 \%$ for the 1934 Term; $82.1 \%$ for the fractious 1935 Term; and $79.2 \%$ during the 1936 Term. With the addition of the Roosevelt appointees beginning in the 1937 Term, however, unanimity rates began a decline from which they would never recover: $69.7 \%$ for the 1937 Term; $64 \%$ for the 1938 Term; $69.3 \%$ for the 1939 Term; and $71.5 \%$ for Hughes's last Term as Chief Justice. And after Hughes departed the
Bench, it would be the exceedingly rare Term that would produce a unanimity rate exceeding $50 \% .^{210}$ The early Terms of the Hughes Court thus constituted the twilight of a longstanding set of institutional norms and practices.

Author's Note: Thanks to Matthew Hofstedt, Devon Burge, Franz Jantzen, Lauren Morrell, Nikki Peronace, and Erin Huckle, all of the Office of the Curator of the Supreme Court of the United States, for their kind hospitality and splendid assistance with the Hughes Court docket books; to Dwight King, Kent Olson, Cathy Palombi, and Jon Ashley for their cheerful and excellent research assistance; and to participants in the Notre Dame Law School Faculty Colloquium for valuable comments and conversation.

\section{ENDNOTES}

${ }^{1}$ Professor Daniel Ernst has reported on Justice Butler's entry for Crowell v. Benson, 285 U.S. 22 (1932), in DANIEL R. ERNST, TOCQUEVILLE'S NIGHTMARE: THE ADMINISTRATIVE STATE EMERGES IN AMERICA, 1900-1940, p. 176 n.9 (quoting Butler OT 1931 Docket Book).

2 The cases selected as "major" or "salient" are those that regularly appear in scholarly treatments of the early Hughes Court. See, e.g., WILliAM G. ROSS, THE CHIEF JUSTICESHIP OF CHARLES EVANS HUGHES, 1930-1941 (2007); MICHAEL E. PARRISH, THE HUGHES COURT: JUSTICES, RULINGS, LEGACY (2002); G. EDWARD WHITE, THE CONSTITUTION AND THE NEW DEAL (2000); BARRY CUSHMAN, RETHINKING THE NEW DEAL COURT: THE STRUCTURE OF A CONSTITUTIONAL REVOLUTION (1998); WILLIAM E. LEUCHTENBURG, THE SUPREME COURT REBORN: THE CONSTITUTIONAL REVOLUTION IN THE AGE OF ROOSEVELT (1995); ALPHEUS THOMAS MASON, HARLAN FISKE STONE: PILLAR OF THE LAW (1956); Barry Cushman, The Secret Lives of the Four Horsemen, 83 VA. L. REV. 559 (1997); Richard D. Friedman, Switching Time and Other Thought Experiments: The Hughes Court and Constitutional Transformation, 142 U. PA. L. REV. 1891 (1994). Scholars may differ concerning the inclusion or exclusion of particular cases from this category, and the statistical discussion in the Conclusion must be read with that caveat in mind. 
Notwithstanding such potential differences, however, my effort has been to select cases about which I believe there would be a broad measure of agreement. For other scholarship employing this analytic category, see Forrest Maltzman \& Peter J. Wahlbeck, Strategic Policy Considerations and Voting Fluidity on the Burger Court, 90 AM. POL. SCI. REV. 581, 589 (1996); Robert H. Dorff \& Saul Brenner, Conformity Voting on the United States Supreme Court, 54 J. POLITICS 762, 772, 773 (1992); Timothy M. Hagle \& Harold J. Spaeth, Voting Fluidity and the Attitudinal Model of Supreme Court Decision Making, 44 WESTERN POLITICAL QUARTERLY 119, 124 (1991); Saul Brenner, Timothy Hagle, \& Harold J. Spaeth, Increasing the Size of Minimum Winning Coalitions on the Warren Court, 23 POLITY 309 (1990); Saul Brenner, Timothy M. Hagle, \& Harold J. Spaeth, The Defection of the Marginal Justice on the Warren Court, 42 WESTERN POLITICAL QUARTERLY 409 (1989); Saul Brenner, Fluidity on the Supreme Court: 1956-1967, 26 AM. J. POL. SCI. 388, 389 (1982); Saul Brenner, Fluidity on the United States Supreme Court: A Reexamination, 24 AM. J. POL. SCI. 526, 530 (1980); Ellliot E. Slotnick, Who Speaks for the Court? Majority Opinion Assignment from Taft to Burger, 23 AM. J. POL. SCI. 60 (1979).

3291 U.S. 502 (1934).

4290 U.S. 398 (1934).

5285 U.S. 262 (1932).

6287 U.S. 45 (1932).

7286 U.S. 73 (1932).

8285 U.S. 393 (1932).

9 Pamela C. Corley, Amy Steigerwalt, \& Artemus Ward, Revisiting the Roosevelt Court: The Critical Juncture from Consensus to Dissensus, 38 J. SUP. CT. HIST. 20, 22 (2013); Mark S. Hurwitz \& Drew Noble Lanier, I Respectfully Dissent: Consensus, Agendas, and Policymaking on the U.S. Supreme Court, 1888-1999, 21 REVIEW OF POLICY RESEARCH 429, 429 (2004); Lee Epstein, Jeffrey A. Segal, \& Harold J. Spaeth, The Norm of Consensus on the U.S. Supreme Court, 45 AM. J. POL. SCI. 362, 376 (2001); Gregory A. Caldeira \& Christopher J.W. Zorn, Of Time and Consensual Norms in the Supreme Court, 42 AM. J. POL. SCI. 874, 874-75 (1998); John P. Kelsh, The Opinion Delivery Practices of the United States Supreme Court 1790-1945, 77 WASH. U. L. Q. 137, 161-62 (1999); Thomas G. Walker, Lee Epstein, \& William J. Dixon, On the Mysterious Demise of Consensual Norms in the United States Supreme Court, 50 JOURNAL OF POLITICS 361, 361-62 (1988).

10 HERMAN C. PRITCHETT, THE ROOSEVELT COURT: A STUDY IN JUDICIAL POLITICS AND VALUES, 1937-1947 40, 251 (1948) ("In 1941 divisive forces of some kind hit the Court full force"); Corley, Steigerwalt, \& Ward, 38 J. SUP. CT. HIST. at 47;
Caldeira \& Zorn, 42 AM. J. POL. SCI. at 874-75; Walker, Epstein, \& Dixon, 50 JOURNAL OF POLITICS 362; David Danelski, The Influence of the Chief Justice in the Decisional Process, in JOEL B. GROSSMAN \& RICHARD S. WELLS, eds., CONSTITUTIONAL LAW AND JUDICIAL POLICY MAKING 175 (1972).

11 Compare Stephen C. Halpern \& Kenneth N. Vines, The Judges' Bill and the Role of the U.S. Supreme Court, 30 WESTERN POLITICAL QUARTERLY 471, 481 (1977) (arguing that the enactment of the Judges' bill of 1925, which made the Court's docket almost entirely discretionary, increased the proportion of cases that were legally or politically salient and thus less likely to elicit acquiescence from colleagues inclined to disagree with the majority), with Walker, Epstein, \& Dixon, 50 JOURNAL OF POLITICS at 365-66 (agreeing that "it is possible that a discretionary docket may be one factor, and a necessary one at that, in maintaining high levels of conflict once such patterns are established," but disputing the contention that the 1925 statute was "the primary factor in the alteration of the Court's consensus norms," pointing out that "significant escalation in both the dissent and concurrence rates did not occur until almost fifteen years" after the dramatic increase in the discretionary share of the Court's docket); accord, Caldeira \& Zorn, 42 AM. J. POL. SCI. at 875; Robert Post, The Supreme Court Opinion as Institutional Practice: Dissent, Legal Scholarship, and Decisionmaking in the Taft Court, 85 MINN. L. REV. 1267, 1319-31 (2001) (rejecting the Halpern \& Vines hypothesis on the ground that unanimity rates in certiorari cases were higher than in those falling under the Court's mandatory jurisdiction, and offering alternative reasons, such as changes in external circumstances, in Court personnel, and in the quality of Taft's leadership, for the decline in unanimity on the late Taft Court).

12 Caldeira \& Zorn, 42 AM. J. POL. SCI. at 892. See also Aaron J. Ley, Kathleen Searles, \& Cornell W. Clayton, The Mysterious Persistence of Non-Consensual Norms on the U.S. Supreme Court, 49 TULSA L. REV. 99, 106 (2013) ("the proportion of unanimous decisions was declining prior to Stone's Chief Justiceship"); Marcus E. Hendershot, Mark S. Hurwitz, Drew Noble Lanier, \& Richard L. Pacelle, Jr., Dissensual Decision Making: Revisiting the Demise of Consensual Norms within the U.S. Supreme Court, 20 POLITICAL RESEARCH QUARTERLY 1, 8 (2012) ("the Court's norm of consensus was first challenged by growing levels of dissent in the later years of the Hughes Court"); David M. O'Brien, Institutional Norms and Supreme Court Opinions: On Reconsidering the Rise of Individual Opinions, in CORNELL W. CLAYTON \& HOWARD GILLMAN, eds., SUPREME COURT DECISIONMAKING: NEW INSTITUTIONALIST APPROACHES 103 (1999) ("the demise of the norm of 
consensus preceded Stone's chief justiceship"); Stacia L. Haynie, Leadership and Consensus on the U.S. Supreme Court, 54 JOURNAL OF POLITICS 1158 (1992) (arguing that Stone consolidated a shift in behavioral expectations that began under Hughes). See also Kelsh, 77 WASH. U. L. Q. at 162 ("The most unusual thing about the nonunanimity rate for the $1864-1940$ period is that the last ten years saw a sustained increase. This rate was to shoot up dramatically in the first years of the Stone Court, but the beginnings of the rise can be seen around 1930 "); id. at 173 ("By the 1930s . . Justices had fully accepted the view that separate opinions had a legitimate role in the American legal system.") Compare BENJAMIN N. CARDOZO, LAW AND LITERATURE 34 (1931) (characterizing dissenters as "irresponsible").

13 See, e.g., Epstein, Segal, \& Spaeth, 45 AM. J. POL. SCI. 362 (Waite Court); Maltzman \& Wahlbeck, 90 AM. POL. SCI. REV. 581 (Burger Court); Dorff \& Brenner, 54 J. POLITICS 762 (Vinson, Warren, and Burger Courts); Hagle \& Spaeth, 44 WESTERN POLITICAL QUARTERLY 119 (Warren Court); Brenner, Hagle, \& Spaeth, 23 POLITY 309 (Warren Court); Brenner, Hagle, \& Spaeth, 42 WESTERN POLITICAL QUARTERLY 409 (Warren Court); Brenner, 26 AM. J. POL. SCI. 388 (Warren Court); Saul Brenner, Ideological Voting on the U.S. Supreme Court: A Comparison of the Original Vote on the Merits with the Final Vote, 22 JURIMETRICS 287 (1982) (Vinson and Warren Courts); Brenner, 24 AM. J. POL. SCI. 526 (Vinson and Warren Courts); J. Woodford Howard, Jr., On the Fluidity of Judicial Choice, 62 AM. POL. SCI. REV. 43 (1968) (Stone and Vinson Courts).

14 Eloise C. Snyder. The Supreme Court as a Small Group, 3 SOCIAL FORCES 232, 238 (1958).

15 Woodford Howard, Justice Murphy: The Freshman Years, 18 VAND. L. REV. 473, 474, 476, 477, 484, 488, 505 (1965).

16 Timothy M. Hagle, "Freshman Effects" for Supreme Court Justices, 37 AM. J. POL. SCI. 1142, 1142 (1993). See also Leigh Anne Williams, Measuring Internal Influence on the Rehnquist Court: An Analysis of NonMajority Opinion Joining Behavior, 68 OHIO ST. L. J. 679, 718-19 (2007); Saul Brenner \& Timothy M. Hagle, Opinion Writing and Acclimation Effect, 18 POL. BEHAV. 235 (1996); Paul C. Arledge \& Edward W. Heck, A Freshman Justice Confronts the Constitution: Justice O'Connor and the First Amendment, 45 WESTERN POL. Q. 761, 761-62 (1992); Edward V. Heck \& Melinda Gann Hall, Bloc Voting and the Freshman Justice Revisited, 43 J. POLITICS 852, 85354 (1981); Elliot E. Slotnick, Judicial Career Patterns and Majority Opinion Assignment on the Supreme Court, 41 J. POLITICS 640, 641 (1979).

17 See, e.g., Lee Epstein, Kevin Quinn, Andrew D. Martin, \& Jeffrey E. Segal, On the Perils of Drawing
Inferences about Supreme Court Justices from Their First Few Years of Service, 91 JUDICATURE 168, 179 (2008) (finding evidence of ideological instability in the merits voting of "virtually all" freshman Justices); Mark S. Hurwitz \& Joseph V. Stefko, Acclimation and Attitudes: "Newcomer" Justices and Precedent Conformance on the Supreme Court, 57 POL. RES. Q. 121 (2004) (finding freshman effect with respect to conformity to precedent); Charles R. Shipan, Acclimation Effects Revisited, 40 JURIMETRICS 243 (2000) (finding evidence of ideological instability in the merits voting of some but not most freshmen Justices on the Warren and Burger Courts); Sandra L. Wood, Linda Camp Keith, Drew Noble Lanier, \& Ayo Ogundele, "Acclimation Effects" for Supreme Court Justices: A Cross-Validation, 1888-1940, 42 AM. J. POL. SCI. 690, 694 (1998) (finding "some evidence of an acclimation effect for at least some of the justices" with respect to ideological instability in merits voting); Brenner \& Hagle, 18 POL. BEHAV. 235 (finding freshman effect with respect to opinion output); Timothy M. Hagle, A New Test for the Freshman Effect, 21 SOUTHEASTERN POL. REV. 289 (1993) (finding evidence of ideological instability in the merits voting of some freshman Justices on the Burger and Rehnquist Courts); Hagle, 37 AM. J. POL. SCI. 1142 (finding evidence of ideological instability in the merits voting of some Justices joining the Court between 1953 and 1989); S. Sidney Ulmer, Toward a Theory of SubGroup Formation in the United States Supreme Court, 27 J. POLITICS 133, 151 (1965) (finding some evidence of freshman effect in bloc voting for Justices joining the Court between 1946 and 1961).

18 See, e.g., Paul J. Wahlbeck, James F. Spriggs II, \& Forrest Maltzman, The Politics of Dissents and Concurrences on the U.S. Supreme Court, 27 AMERICAN POLITICS QUARTERLY 488, 503-04 (1999) (“Contrary to the freshman effect hypothesis, freshman justices are no less likely to join or author a concurring or dissenting opinion than their more senior colleagues"); Richard Pacelle \& Patricia Pauly, The Freshman Effect Revisited: An Individual Analysis, 17 AM. REV. POLITICS 1, 6, 15 (1996) (finding no freshman effect with respect to ideological instability in merits votes in the aggregate, and "only limited evidence" of such an effect with respect to individual justices joining the Court between 1945 and 1988); Terry Bowen, Consensual Norms and the Freshman Effect on the United States Supreme Court, 76 SOC. SCI. Q. 222, 227 (1995) (finding no freshman effect for separate opinion writing on the Hughes and Taft Courts, but finding such a freshman effect during the 1941-1992 period); Terry Bowen \& John M. Scheb II, Freshman Opinion Writing on the U.S. Supreme Court, 1921-1991, 76 JUDICATURE 239 (1993) (finding no freshman effect with respect to opinion assignments); Robert L. Dudley, The 
Freshman Effect and Voting Alignments: A Reexamination of Judicial Folklore, 21 AM. POLITICS Q. 360 (1993) (finding no freshman effect with respect to bloc voting even when using Snyder's data); Terry Bowen \& John M. Scheb II, Reassessing the "Freshman Effect": The Voting Bloc Alignment of New Justices on the United States Supreme Court, 1921-90, 15 POL. BEHAV. 1 (1983) (finding no freshman effect with respect to bloc voting); Heck \& Hall, 43 J. POLITICS 852 (finding very little evidence of a freshman effect in bloc voting on the Warren and Burger Courts); Slotnick, 41 J. POLITICS 640 (finding no freshman effect with respect to opinion assignments). For efforts to explain the divergences in scholarly findings, see Hagle, 21 SOUTHEASTERN POL. REV. 289; Hagle, 37 AM. J. POL. SCI. 1142; Albert P. Melone, Revisiting the Freshman Effect Hypothesis: The First Two Terms of Justice Anthony Kennedy, 74 JUDICATURE 6, 13 (1990); Heck \& Hall, 43 J. POLITICS at 859-60.

19 See, e.g., Thomas R. Hensley, Joyce A. Baugh, \& Christopher E. Smith, The First-Term Performance of Chief Justice John Roberts, 43 IDAHO L. REV. 625, 631 (2007) (finding no freshman effect with respect to bloc voting); Christopher E. Smith \& S. Thomas Read, The Performance and Effectiveness of New Appointees to the Rehnquist Court, 20 OHIO N. U. L. REV. 205 (1993) (finding a freshman effect with respect to Justice Souter but not with respect to Justice Thomas); Arledge \& Heck, 45 WESTERN POL. Q. 761 (finding no freshman effect); Melone, 74 JUDICATURE 6 (finding a freshman effect only with respect to majority opinion assignments); Thea F. Rubin \& Albert P. Melone, Justice Antonin Scalia: A First Year Freshman Effect?, 72 JUDICATURE 98 (1988) (finding a freshman effect only with respect to majority opinion assignments); John M. Scheb II \& Lee W. Ailshie, Justice Sandra Day O'Connor and the Freshman Effect, 69 JUDICATURE 9 (1985) (finding evidence of a freshman effect only with respect to majority opinion assignments in her first Term); Edward V. Heck, The Socialization of a Freshman Justice: The Early Years of Justice Brennan, 10 PAC. L. J. 707, 71416, 722-25 (1979) (finding little evidence of a freshman effect).

${ }^{20}$ Howard, Jr., 62 AM. POL. SCI. REV. at 45. The clerk to which Howard referred was Paul Freund, who clerked for Justice Brandeis during the 1932 Term. See Paul Freund, A Tale of Two Terms, 26 OHIO ST. L. J. 225, 227 (1965) ("I was struck in the 1932 Term with the number of occasions on which what came down as unanimous opinions had been far from that at conference. I had access to the docket book which the Justice kept as a record of the conference vote- these books are destroyed at the end of each term-and I was enormously impressed with how many divisions there were that did not show up in the final vote. I was impressed with how often Justice Cardozo was in a minority, often of one, at conference, but did not press his position.")

21 Howard, Jr., 62 AM. POL. SCI. REV. at 45.

22 Compare Maltzman \& Wahlbeck, 90 AM. POL. SCI. REV. at 589 (finding that "freshmen justices are significantly more likely to switch than are their more senior colleagues"), Saul Brenner, Another Look at Freshman Indecisiveness on the United States Supreme Court, 16 POLITY 320 (1983) (finding that between the 1946 and 1966 Terms freshman Justices exhibited on average greater fluidity between the conference vote and the final vote on the merits than did senior Justices, and that this fluidity tended to diminish between a Justice's first and fourth Terms on the Court), and Dorff \& Brenner, 54 J. POLITICS at 767, 769-71 (finding that freshman Justices were "more likely to be uncertain regarding how to vote at the original vote on the merits and more likely to be influenced by the decision of the majority at the final vote") with Hagle \& Spaeth, 44 WESTERN POLITICAL QUARTERLY 119 (finding that the voting fluidity of freshman Justices on the Warren Court did not differ significantly from that of their more senior colleagues, and that the voting fluidity of such freshman Justices had not diminished by their third and fourth Terms on the Court). See also Timothy R. Johnson, James F. Spriggs II, \& Peter J. Wahlbeck, Passing and Strategic Voting on the U.S. Supreme Court, 39 LAW \& SOCIETY REV. 349, 369 (2005) (finding that freshman Justices on the Burger Court did not pass more frequently than their senior colleagues).

23 I do not treat Hughes, who was appointed Chief Justice in 1930, as a freshman, due to his prior service as an Associate Justice from 1910-1916.

24280 U.S. iii.

25281 U.S. iii.

26284 U.S. iii.

27285 U.S. iii.

${ }^{28}$ DENNIS J. HUTCHINSON \& DAVID J. GARROW, eds., THE FORGOTTEN MEMOIR OF JOHN KNOX 84 (2002).

29 Chief Justice William H. Rehnquist and Professor Paul A. Freund: “A Colloquy,” Proceedings of the FortyNinth Judicial Conference of the District of Columbia Circuit (May 24, 1989), reprinted in 124 F.R.D. 241, 347 (1988).

30 With the exception of the Van Devanter OT 1931 Docket Book, which was donated to the Curator's office in the 1990 s by a descendant of a former law clerk, each of these docket books remained in the Supreme Court building after the respective Justice either retired or died while in office. It is not known why these volumes were retained, nor why not all of the sets of docket books are complete. In 1972 all of the "historic" docket books held in the Supreme Court building were boxed up by the Court's Marshal at the order of Chief Justice Warren 
Burger, and were later transferred to the Curator's Office. Email communication from Matthew Hofstedt, Associate Curator, Supreme Court of the United States, August 26, 2014.

31 This is also sometimes referred to as "conformity voting," see, e.g., Dorff \& Brenner, 54 J. POLITICS at 763; or "minority-majority voting," see, e.g., Saul Brenner \& Robert H. Dorff, The Attitudinal Model and Fluidity Voting on the United States Supreme Court: A Theoretical Perspective, 4 JOURNAL OF THEORETICAL POLITICS 195, 197 (1992).

32 I borrow this term from Brenner, 22 JURIMETRICS at 287. What Professor Brenner calls the "original vote on the merits" I refer to as the "conference vote."

33 These two terms are adapted from Brenner, 26 AM. J. POL. SCI. at 388, and Brenner, 24 J. POL. SCI. at 527 (referring to such movements as "strong fluidity" and "weak fluidity," respectively.)

34 See, e.g., Brenner \& Dorff, 4 JOURNAL OF THEORETICAL POLITICS at 200 (concluding that Justices acquiesce "for non-attitudinal reasons, including small-group reasons"); Howard, Jr., 62 AM. POL. SCI. REV. at 45 (1968) (same).

35 This is also sometimes referred to as "counterconformity voting," see, e.g., Dorff \& Brenner, $54 \mathrm{~J}$. POLITICS at 763 ; or "majority-minority voting," see, e.g., Brenner \& Dorff, 4 JOURNAL OF THEORETICAL POLITICS at 197.

${ }^{36}$ Id. There also are instances in which a docket book entry does not record a vote for a particular Justice. Often that was because the Justice was absent from the conference, and where that was the case, I do not treat that Justice as having engaged in any of the defined voting behaviors.

37 See, e.g., Sproles v. Binford, 286 U.S. 374 (1932) (upholding statute limiting the size and weight of vehicles), Stone OT 1931 Docket Book; Butler OT 1931 Docket Book; Roberts OT 1931 Docket Book; Mintz v. Baldwin, 289 U.S. 346 (1933) (upholding power of state to require inspection and certification of imported cattle in order to prevent the spread of infectious disease), Stone OT 1932 Docket Book; Butler OT 1932 Docket Book; Roberts OT 1932 Docket Book; and Corporation Commission of Oklahoma v. Lowe, 281 U.S. 431 (1930) (refusing competing cotton ginner's request that licensure of a farmer's cooperative cotton gin be enjoined), Stone OT 1929 Docket Book. Sanford and McReynolds were absent from the conference, but all of those present voted to deny the injunction.

38292 U.S. 40 (1934); Stone OT 1933 Docket Book; Butler OT 1933 Docket Book; Roberts OT 1933 Docket Book.

39 Butler OT 1933 Docket Book. By contrast, the Justices unanimously protected private property rights from executive interference in Sterling v. Constantin,
287 U.S. 378 (1932). There the Court held that alleged overproduction of oil in Texas had not created an emergency authorizing the governor to declare martial law, seize control of private oil wells by military force, and discontinue their production of oil. The vote in conference also was unanimous. Stone OT 1932 Docket Book; Butler OT 1932 Docket Book; Roberts OT 1932 Docket Book; Cardozo OT 1932 Docket Book.

40 See Carter v. Carter Coal Co., 298 U.S. 238, 303 (1936) (citing Champlin and Pfost).

41286 U.S. 165 (1932); Roberts OT 1931 Docket Book. Stone's OT 1931 Docket Book does not make it clear whether Cardozo voted, and Butler's OT 1931 Docket Book contains no record of the vote.

42 Butler OT 1931 Docket Book. See also Champlin Refining Co. v. Corporation Commission of Oklahoma, 286 U.S. 210 (1932) (sustaining an Oklahoma statute prohibiting wasteful production of petroleum on the ground that it applied only to "production"), Stone OT 1931 Docket Book; Butler OT 1931 Docket Book; Roberts OT 1931 Docket Book; Levering \& Garrigues Co. v. Morrin, 289 U.S. 103 (1933) (holding that a strike and boycott for a closed shop in the building industry was a "local matter" beyond the reach of the Sherman Act), Stone OT 1932 Docket Book; Butler OT 1932 Docket Book; Roberts OT 1932 Docket Book (Butler reporting that at the conference McReynolds voted with the majority "doubtfully"); Chassaniol v. City of Greenwood, 291 U.S. 584, 587 (1934) (upholding local occupation tax on cotton buyers on grounds that their activities were "intrastate commerce"). Both Butler and Roberts record the conference vote, like the final decision, as unanimous. Butler records Hughes as stating at the conference, "Enough intra state." Butler OT 1933 Docket Book; Roberts OT 1933 Docket Book. Stone's OT 1933 Docket Book contains an indication that the opinion was assigned to Brandeis, but no account of the conference vote.

43281 U.S. 548 (1930); Stone OT 1929 Docket Book. McReynolds did not participate.

${ }^{44}$ Houston, E. \& W. T. Ry. Co. v. United States, 234 U.S. 342 (1914).

${ }^{45}$ Florida v. United States, 292 U.S. 1 (1934) (upholding power of ICC to increase intrastate rates); Stone OT 1933 Docket Book; Butler OT 1933 Docket Book; Roberts OT 1933 Docket Book; Ohio v. United States, 292 U.S. 498 (1934) (upholding ICC order raising intrastate rates for shipment of bituminous coal in order to end interstate discrimination); Stone OT 1933 Docket Book; Butler OT 1933 Docket Book; Roberts OT 1933 Docket Book. Butler records that at the Ohio conference Hughes stated, "Read findings. Interstate rates reasonable. Intra unduly pref. \& prej. We can't go into qu of relation of outer crescent. No qu of law presented." Butler OT 1933 Docket Book. 
46292 U.S. 313 (1934); Butler OT 1933 Docket Book; Roberts OT 1933 Docket Book.

47292 U.S. at 317.

48 Butler OT 1933 Docket Book.

49 Stone OT 1933 Docket Book; Butler OT 1933 Docket Book.

50 Butler OT 1933 Docket Book.

51 Stone OT 1933 Docket Book; Butler OT 1933 Docket Book.

52 Butler OT 1933 Docket Book; Roberts OT 1933 Docket Book.

53 See, e.g., United States v. Benz, 282 U.S. 304 (1931) (upholding trial judge's order shortening the sentence that a convict already had begun to serve against the claim that it usurped the executive's pardoning power), Stone OT 1930 Docket Book; Roberts OT 1930 Docket Book; District of Columbia v. Colts, 282 U.S. 63 (1930) (holding that one prosecuted for reckless driving in the District of Columbia was entitled to be tried before a jury), Stone OT 1930 Docket Book; Roberts OT 1930 Docket Book; Morrison v. California, 291 U.S. 82 (1934) (reversing conviction for conspiracy to violate California's Alien Land Law), Stone OT 1933 Docket Book; Butler OT 1933 Docket Book; Roberts OT 1933 Docket Book; United States v. Chambers, 291 U.S. 217 (1934) (holding that all prosecutions for violations of the Prohibition Act pending at the time the Twenty-First Amendment had been ratified had to be dropped), Stone OT 1933 Docket Book; Butler OT 1933 Docket Book; Roberts OT 1933 Docket Book (McReynolds was absent from the conference); Taylor $v$. United States, 286 U.S. 1 (1932) (reversing conviction based on evidence secured through warrantless search of garage from which Prohibition agents had detected the odor of whiskey), Stone OT 1931 Docket Book; Butler OT 1931 Docket Book; Roberts OT 1931 Docket Book. Butler records Hughes as stating, "Garage within curtilage part of the dwelling. . . Generally unreasonable.” Butler OT 1931 Docket Book.

54290 U.S. 41 (1933); Stone OT 1933 Docket Book; Butler OT 1933 Docket Book; Roberts OT 1933 Docket Book.

55289 U.S. 466 (1933); Stone OT 1932 Docket Book; Butler OT 1932 Docket Book; Roberts OT 1932 Docket Book.

56281 U.S. 370 (1930); Stone OT 1929 Docket Book. Sanford and McReynolds were absent from the conference, but all of those present voted to uphold the appropriation.

57283 U.S. 553 (1931).

58 Stone OT 1930 Docket Book. This characterization may be a reflection of notations in Roberts's docket book indicating that three of the Justices initially voted the other way. Roberts's record shows votes to affirm crossed out, with votes to reverse entered next to them, for Holmes, Brandeis, and Stone. Roberts OT 1930 Docket Book.

59290 U.S. 1 (1933); Stone OT 1933 Docket Book records Sutherland as dissenting at conference; Butler OT 1933 Docket Book records him as passing; Roberts OT 1933 Docket Book records him as "Not Voting." 60290 U.S. 570 (1934); Stone OT 1933 Docket Book; Butler OT 1933 Docket Book. Roberts recorded the vote as unanimous. Roberts OT 1933 Docket Book.

61292 U.S. 426 (1934) (Van Devanter, McReynolds, Sutherland, and Butler concurred specially); Stone OT 1933 Docket Book; Butler OT 1933 Docket Book; Roberts OT 1933 Docket Book.

62291 U.S. 67 (1934); Stone OT 1933 Docket Book; Butler OT 1933 Docket Book; Roberts OT 1933 Docket Book.

63291 U.S. 304 (1934); Stone OT 1933 Docket Book; Roberts OT 1933 Docket Book; Butler OT 1933 Docket Book (Hughes describing the practice in question as "reprehensible").

64286 U.S. 123 (1932); Stone OT 1931 Docket Book; Butler OT 1931 Docket Book; Roberts 1931 OT Docket Book. Stone has an erased vote in the Chief Justice's column, which might suggest a possible change of vote on his part. However, no such record appears in either the Butler or the Roberts docket books.

65290 U.S. 70 (1933); Stone OT 1933 Docket Book; Butler OT 1933 Docket Book; Roberts OT 1933 Docket Book.

66 Butler OT 1933 Docket Book.

67282 U.S. 568 (1931).

68132 S. Ct. 2566 (2012).

69 Stone records Brandeis as voting with Holmes and Stone, and records no vote for McReynolds. Stone OT 1930 Docket Book. Roberts, by contrast, lists both McReynolds and Brandeis as voting with the majority, though he has a crossed-out vote the other way in the Brandeis column, suggesting that Brandeis may have changed his vote at the conference. Roberts OT 1930 Docket Book. Stone later wrote to Felix Frankfurter that Brandeis's opinion in Helvering v. Mitchell, 303 U.S. 391 (1938) "reaches finally a result which I tried very hard to have the Court adopt in the La Franca case." Stone to Frankfurter, March 7, 1938, quoted in MASON, HARLAN FISKE STONE at 556.

70281 U.S. 276 (1930). Hughes took no part in the decision. Sanford agreed to the disposition before his untimely death. Id. at 313 .

71 Stone OT 1929 Docket Book.

72282 U.S. 687 (1931); Stone OT 1930 Docket Book; Robert OT 1930 Docket Book.

73 Stone OT 1931 Docket Book; Roberts OT 1931 Docket Book.

74285 U.S. 452 (1932). Cardozo took no part in the decision. 
75 Butler OT 1931 Docket Book.

76287 U.S. 112 (1932); Stone OT 1932 Docket Book; Butler OT 1932 Docket Book; Roberts OT 1932 Docket Book; Cardozo OT 1932 Docket Book.

77 Butler OT 1932 Docket Book.

78282 U.S. 251 (1931); Stone OT 1930 Docket Book; Roberts OT 1930 Docket Book.

79290 U.S. 398 (1934); Stone OT 1933 Docket Book; Butler OT 1933 Docket Book; Roberts OT 1933 Docket Book.

${ }^{80}$ Butler OT 1933 Docket Book. See 290 U.S. at 421 n.3.

81 Butler OT 1933 Docket Book. See 189 Minn. 422, 429-30 (1933).

82 Butler OT 1933 Docket Book. See 290 U.S. at 423.

83 Butler OT 1933 Docket Book. See 290 U.S. at 423 n.4.

${ }^{84}$ Butler OT 1933 Docket Book. See 290 U.S. at 423 n.4.

85199 U.S. 473 (1905). Butler OT 1933 Docket Book.

86290 U.S. at 437. Hughes also made "Reference to difference between 'direct' and 'incidental.' 'Emergency' may authorize direct-earthquake \& 'Economic' may be the same-The question is 'does such an emergency exist?"” Butler OT 1933 Docket Book.

86291 U.S. 502 (1934).

87291 U.S. 502 (1934); Stone OT 1933 Docket Book; Butler OT 1933 Docket Book; Roberts OT 1933 Docket Book.

88 Butler OT 1933 Docket Book.

89285 U.S. 262 (1932). See infra.

90262 U.S. 522 (1923).

91 Butler OT 1933 Docket Book.

92291 U.S. at 511-14.

93287 U.S. 45 (1932).

94 See JAMES GOODWIN, STORIES OF SCOTTSBORO (1994); DAN T. CARTER, SCOTTSBORO: A TRAGEDY OF THE AMERICAN SOUTH (rev. ed. 1979).

95 Stone OT 1932 Docket Book; Butler OT 1932 Docket Book; Roberts OT 1932 Docket Book.

96 Butler OT 1932 Docket Book.

97287 U.S. 206 (1932).

98 Stone OT 1932 Docket Book; Butler OT 1932 Docket Book; Roberts OT 1932 Docket Book; Cardozo OT 1932 Docket Book.

99 Butler OT 1932 Docket Book; Roberts OT 1932 Docket Book.

100287 U.S. at 215-16.

101 Id. at 210-11.

102 Butler OT 1932 Docket Book.

103 Butler OT 1932 Docket Book; Roberts OT 1932 Docket Book.

104 Roberts OT 1932 Docket Book.

105 See also Grau v. United States, 287 U.S. 124 (1932)

(holding 7-2, with Stone and Cardozo dissenting both at conference and from the published decision, that the warrant authorizing a search was invalid); Stone OT 1932 Docket Book; Butler OT 1932 Docket Book; Roberts OT 1932 Docket Book; Cardozo OT 1932 Docket Book.

106283 U.S. 359 (1931); Roberts OT 1930 Docket Book. 107283 U.S. 697 (1931); Stone OT 1930 Docket Book; Roberts OT 1930 Docket Book.

108283 U.S. 605 (1931); Stone OT 1930 Docket Book; Roberts OT 1930 Docket Book. MacIntosh was anticipated by the late Taft Court decision in Schwimmer v. United States, 279 U.S. 644 (1929), which upheld the denial of naturalization to a forty-nine-year-old foreign woman who would not swear to take up arms in defense of the United States. The final vote was 6-3, with Holmes, Brandeis, and Sanford dissenting. Stone listed the conference vote as 5-3 with Sutherland absent, but he placed a question mark next to Sanford's dissenting vote, and wrote next to his own ultimate vote with the majority, presumably entered later, "passed on the final vote." Stone OT 1928 Docket Book. See RONALD B. FLOWERS, TO DEFEND THE CONSTITUTION: RELIGION, CONSCIENTIOUS OBJECTION, NATURALIZATION, AND THE SUPREME COURT (2003).

109273 U.S. 536 (1927).

110286 U.S. 73 (1932).

111 Stone OT 1931 Docket Book.

112 Roberts OT 1931 Docket Book.

113 Butler OT 1931 Docket Book.

114290 U.S. 371 (1933); Stone OT 1933 Docket Book; Butler OT 1933 Docket Book; Roberts OT 1933 Docket Book.

115290 U.S. 389 (1933).

116 Butler OT 1933 Docket Book; Roberts OT 1933 Docket Book. Stone OT 1933 Docket Book records the vote as 5-2 with Brandeis not voting, but this appears to be an error.

117287 U.S. 435 (1932); Stone OT 1932 Docket Book; Butler OT 1932 Docket Book; Roberts OT 1932 Docket Book; Cardozo OT 1932 Docket Book.

118283 U.S. 636 (1931); Stone OT 1930 Docket Book; Roberts OT 1930 Docket Book.

119291 U.S. 559 (1934); Stone OT 1933 Docket Book; Butler OT 1933 Docket Book; Roberts OT 1933 Docket Book.

120285 U.S. 424 (1932).

121 Id. at 425.

122 Stone OT 1931 Docket Book.

123 Butler OT 1931 Docket Book.

124285 U.S. 262 (1932); Stone OT 1931 Docket Book; Butler OT 1931 Docket Book; Roberts OT 1931 Docket Book.

125 Butler OT 1931 Docket Book.

126 See, e.g., Melvin I. Urofsky, The BrandeisFrankfurter Conversations, 1985 SUP. CT. REV. 299, 
317 (Brandeis opining that "McR. cares more about jurisdictional restraints than any of them").

127 Butler OT 1931 Docket Book.

128 See Truax v. Raich, 239 U.S. 33, 31 (1915) (Hughes,

J.) ("It requires no argument to show that the right to work for a living in the common occupations of the community is of the very essence of the personal freedom and opportunity that it was the purpose of the [Fourteenth] Amendment to secure.").

129 See, e.g., Mayflower Farms, Inc. v. Ten Eyck, 297 U.S. 266, 273 (1936) (Roberts, J., in an opinion joined by Hughes, C.J.) (striking down a statute that effectively provided that "during the life of the law no person or corporation might enter the business of a milk dealer in New York City"); United States v. Rock Royal Cooperative, 307 U.S. 533, 587 (1939) (Roberts, J., in a dissenting opinion joined by Hughes, C.J.) (objecting to a federal milk marketing regulation that "inevitably tend[ed] to destroy the business of smaller [milk] handlers by placing them at the mercy of their larger competitors.").

130 Butler OT 1931 Docket Book.

131 Chickasha Cotton Oil Co. v. Cotton County Co., 40 F.2d $846\left(10^{\text {th }}\right.$ Cir. 1930).

132285 U.S. at 263.

133285 U.S. at $276-77$.

134 Id. at 277-79.

135287 U.S. 251 (1932).

136287 U.S. at 264.

137 Butler OT 1932 Docket Book.

138 Stone OT 1932 Docket Book; Butler OT 1932 Docket Book; Roberts OT 1932 Docket Book; Cardozo OT 1932 Docket Book.

139 A third state police power case, Louis K. Liggett Co. v. Lee, 288 U.S. 517 (1933), held that a statute imposing a heavier privilege tax per store on an owner whose stores were in different counties than on an owner whose stores were all in the same county was arbitrary and violated the guarantees of the Fourteenth Amendment. The final vote was 6-3, with Brandeis, Stone, and Cardozo dissenting, but at the conference Stone passed. Butler OT 1932 Docket Book; Roberts OT 1932 Docket Book; Cardozo OT 1932 Docket Book. Stone records the vote as 5-3 to reverse, with Brandeis, Roberts, and Cardozo dissenting and Stone passing, suggesting that Roberts changed his vote after conference. Two years earlier, the Court had upheld a progressive tax on chain stores in State Board of Tax Commissioners v. Jackson, 283 U.S. 527 (1931). Both the conference vote and the final vote on the merits had been 5-4, with the Four Horsemen in dissent. Stone OT 1930 Docket Book; Roberts OT 1930 Docket Book. 140282 U.S. 379 (1931); Stone OT 1930 Docket Book; Roberts OT 1930 Docket Book.

141283 U.S. 570 (1931); Stone OT 1930 Docket Book; Roberts OT 1930 Docket Book.

142277 U.S. 218 (1928).
143283 U.S. at 579.

144285 U.S. 393 (1932).

145257 U.S. 501 (1922).

146285 U.S. at 398.

147285 U.S. at 401.

148285 U.S. at 406-10.

149285 U.S. 393.

150 Stone OT 1931 Docket Book; Butler OT 1931

Docket Book; Roberts OT 1931 Docket Book.

151284 U.S. iii.

152 Butler OT 1931 Docket Book.

153 Stone OT 1931 Docket Book; Butler OT 1931 Docket Book; Roberts OT 1931 Docket Book.

154285 U.S. iii.

155 Stone OT 1931 Docket Book; Butler OT 1931 Docket Book; Roberts OT 1931 Docket Book.

156285 U.S. 393.

157 Stone OT 1931 Docket Book; Butler OT 1931 Docket Book; Roberts OT 1931 Docket Book.

${ }^{158}$ Another notable case involving a question of federal power that witnessed vote changes between conference and final decision was Chicago, Rock Island \& Pacific Railway Co. v. United States, 284 U.S. 80 (1931), which invalidated an ICC order exempting certain "short line" railroads from the obligation to pay a reasonable daily rental fee for the use of other railroads' cars under certain circumstances. The vote in conference was $6-1$, with Brandeis dissenting and Holmes and Stone passing. Stone OT 1931 Docket Book; Butler OT 1931 Docket Book; Roberts OT 1931 Docket Book. In the published decision, however, both Holmes and Stone joined Brandeis's dissent.

159285 U.S. 22 (1932).

160 Stone OT 1931 Docket Book; Butler OT 1931 Docket Book; Roberts OT 1931 Docket Book. Mason mistakenly asserts that "[a]t conference they had split 5 to 3." MASON, HARLAN FISKE STONE at 337. Mason was perhaps led to this view because Stone wrote to Hughes after the conference, "At the conference I expressed doubt as to the construction given to the statute by the majority of the Court, which doubt still persists." Stone to Hughes, Dec. 18, 1931, quoted in MASON, HARLAN FISKE STONE at 338. The details of the Stone and Roberts defections are well explained in DANIEL R. ERNST, TOCQUEVILLE'S NIGHTMARE: THE ADMINISTRATIVE STATE EMERGES IN AMERICA, 1900-1940, pp. 176 n.9, 177 n.12 (2014). 161 See MERLO J. PUSEY, CHARLES EVANS HUGHES 284 (1951) (discussing what Sutherland referred to as Van Devanter's "pen paralysis").

162 ARTHUR M. SCHLESINGER, JR., THE POLITICS OF UPHEAVAL 456 (1960).

163 No. 66, Northport Power \& Light Co. v. Hartley. Stone OT 1930 Docket Book; Roberts OT 1930 Docket Book. 
164 No. 81, Choteau v. Burnet. Stone OT 1930 Docket Book; Roberts OT 1930 Docket Book.

165 No. 263, Maas \& Waldsetin Co. v. U.S. Stone OT 1930 Docket Book; Roberts OT 1930 Docket Book.

166 Nos. 170, 245, Gregg Dyeing Co. v. Query, Butler OT 1931 Docket Book; No. 790, Edwards v. U.S., Stone OT 1931 Docket Book.

167 No. 158, Shriver v. Woodbine Savings Bank. Stone OT 1931 Docket Book; Roberts OT 1931 Docket Book.

168 No. 598, Michigan v. Michigan Trust Co. Stone OT 1931 Docket Book. Butler records that the initial vote was taken on April 23, 1932, but that on April 30 McReynolds "Returned case to conference- new vote." Butler OT 1931 Docket Book.

169286 U.S. 334, 346 (McReynolds, J., dissenting).

${ }^{170}$ No. 1, Texas \& Pacific Ry. Co. v. United States. Stone OT 1932 Docket Book; Butler OT 1932 Docket Book.

171 Nos. 5-8-9, Original, Wisconsin v. Illinois. Stone OT 1932 Docket Book.

172 Nos. 316-318, U.S. v. Dubilier Condenser Corp. Butler OT 1932 Docket Book.

173289 U.S. 178, 209 (1933).

174 No. 55, Sgro v. U.S. Butler OT 1932 Docket Book; Roberts OT 1932 Docket Book. McReynolds filed a concurring opinion, 287 U.S. 206, 212 (1932) (McReynolds, J., concurring).

175 No. 298, Nickey v. Mississippi. Stone OT 1933 Docket Book; Butler OT 1933 Docket Book; Roberts OT 1933 Docket Book.

176 No. 561, International Milling Co. v. Columbia Transport Co. Stone OT 1933 Docket Book; Butler OT 1933 Docket Book; Roberts OT 1933 Docket Book.

${ }^{177}$ No. 463, Elliot v. Lombard. Stone OT 1933 Docket Book; Butler OT 1933 Docket Book.

178 See, e.g., Sgro v. United States, 287 U.S. at 212 (Stone and Cardozo dissent from opinion holding search unconstitutional); Grau v. United States, 287 U.S. at 129 (Stone and Cardozo dissent from opinion holding search unconstitutional); see also Palko v. Connecticut, 302 U.S. 319 (1937) (Cardozo writes and Stone joins opinion holding that the Double Jeopardy Clause does not apply to state criminal prosecutions).

179 Recollection of Herbert Wechsler in KATIE LOUCHHEIM, THE MAKING OF THE NEW DEAL: THE INSIDERS SPEAK 53 (1983) (Stone "thought Butler was too soft in dealing with criminal matters").

${ }^{180}$ See, e.g., Maltzman \& Wahlbeck, 90 AM. POL. SCI. REV. at 590-91 (finding that Justices were more likely to move from a dissenting conference vote to the majority than to defect from the conference majority); Brenner \& Dorff, 4 JOURNAL OF THEORETICAL POLITICS at 198 (finding that movement from conference minority to ultimate majority is the most frequent type of vote fluidity); Brenner, 26 AM. J. POL. SCI. at 389 (finding that $68 \%$ of the cases in which there was vote fluidity resulted in an increase in the size of the majority); Brenner, 24 AM. J. POL. SCI. at 531, 534 ("justices are more likely to switch from the minority or nonparticipation at the original vote to the majority position at the final vote than to shift in the opposite direction ... Clearly, some of the justices, once they have lost at the original vote or failed to participate in that vote, are willing to conform to the opinion of the court's majority and vote with them at the final vote. Indeed, over threequarters of the vote changes moved in a consensus direction.")

181 Four of McReynolds's seven acquiescences in ultimately unanimous case were strong (Keppel Bros., Fox Film, U.S. v. Louisiana, Alford), while three were weak (Cahoon, Algoma Lumber, Lefkowitz). Of Sutherland's three such acquiescences, at least two (Fox Film, U.S. v. Louisiana) were strong, while his acquiescence in Blasius may have been either strong or weak, depending upon which docket book one consults. Brandeis's acquiescence in U.S. v. Louisiana was technically weak, though Butler's conference notes suggest that he was initially inclined to dissent. The docket books also suggest that his acquiescence in LaFranca was of the strong variety. Stone strongly acquiesced in LaFranca but only weakly in Worthen. The acquiescences of Holmes in LaFranca, Butler in Patton, and Cardozo in Gebardi each were strong, while Van Devanter's acquiescence in Bryan was weak. Roberts's docket book also suggests that Holmes, Brandeis, and Stone may have acquiesced in Cahoon, but Stone's record does not corroborate this.

182 McReynolds acquiesced strongly in Binford and Educational Films, but weakly in Murdock. Brandeis acquiesced strongly in Gebardi, Funk, and Hansen. Van Devanter acquiesced strongly in Funk, as did Butler and Sutherland in Limehouse, while Cardozo did so weakly in Sorrells. Stone's docket book suggests that Roberts may have acquiesced strongly in Liggett, but this is corroborated by neither the Butler nor the Roberts nor the Cardozo docket books.

183 McReynolds did not participate in the conference votes in Railway Clerks, Lowe, Chambers, or Cochran. 184 Saul Brenner, Ideological Voting on the Vinson Court: A Comparison of Original \& Final Votes on the Merits, 22 POLITY 157, 163 (1989). An examination of these cases also provides some indication of the comparative success of the Justices in preparing opinions that would attract colleagues who had dissented or passed at conference. There were thirteen major cases that became unanimous after a divided conference vote. Hughes (Cahoon, Blasius, Worthen, Doyal) and Stone (Keppel Bros., U.S. v. Louisiana, Alford, Gebardi) each accounted for $30.7 \%$ of these cases. Butler (Petersen 
Baking, Lefkowitz) and Sutherland (LaFranca, Patton) each accounted for $15.4 \%$, and Cardozo (Algoma Lumber) accounted for $7.7 \%$. Neither Holmes, Van Devanter, McReynolds, Brandeis, nor Roberts was responsible for any of these decisions. This phenomenon can also be examined by looking at the percentage of unanimous opinions authored by a Justice that were not unanimous at conference. Here Stone ranked first at $100 \%(4 / 4)$, Butler (1/2) and Cardozo (2/4) second at $50 \%$, Hughes third at $30.7 \%(4 / 13)$, and Sutherland fourth at $28.6 \%(2 / 7)$. The remaining Justices were of course tied at $0 \%$. These data also should be viewed in light of divided major decisions in which the author failed to increase the size of the conference majority. Neither Holmes, Van Devanter, McReynolds, Butler, Stone, nor Cardozo authored any such decisions; but of the thirteen such cases, Hughes was the author of $46.1 \%$ (Blaisdell, Sgro, Stromberg, Near, Sorrells, Crowell), Sutherland of $30.8 \%$ (Powell, McIntosh, Liebmann, Bland), Roberts of $15.4 \%$ (Nebbia, Grau), and Brandeis (O'Gorman) of 7.7\%. One should also consider cases in which the author of an opinion managed to attract additional votes, but failed to achieve unanimity. Roberts did so in four of twelve such cases (Murdock, Hansen $v$. Haff, Liggett, Jackson); Sutherland did so in three (Funk, Stephenson v. Binford, Rock Island); and Van Devanter (Indian Motorcycle), McReynolds (Burnet), Brandeis (Limehouse), Stone (Educational Films), and Cardozo (Condon) in one each. Neither Holmes nor Butler accounted for any such cases. These data also should be read in light of the observation that, "[f]rom 1932 to 1937, Hughes . . . assigned 44 percent of the important constitutional cases to Roberts and Sutherland ... When the liberal bloc dissented, Roberts, who was then a center judge, was assigned 46 percent of the opinions. The remaining 54 percent were divided among the conservatives," with Sutherland taking $25 \%$, Butler $18 \%$, and McReynolds $11 \%$. "When the conservative bloc dissented, Hughes divided 63 percent of those cases between himself and Roberts." Danelski, The Influence of the Chief Justice, at 173-74.

185 See, e.g., Barry Cushman, The Hughes Court Docket Books: The Late Terms, 1937-1940, 55 AM. J. LEG. HIST. _ (forthcoming, December 2015). Other studies have shown that neither Roberts nor Cardozo exhibited a freshman effect with respect to bloc voting. See Dudley, 21 AM. POLITICS Q. at 364-65; Bowen \& Scheb II, 15 POL. BEHAV. at 7, 11.

186 Freund, 26 OHIO ST. L. J. at 227.

187 Some studies of voting fluidity conclude that "justices were no more likely to change their votes in important, or salient, cases than in those of lesser importance." Hagle \& Spaeth, 44 WESTERN POLITICAL QUARTERLY at 124. See also Maltzman \& Wahlbeck, 90 AM. POL. SCI. REV. at 589 (finding that "justices are not less likely to switch in salient cases"); Brenner, Hagle, \& Spaeth, The Defection of the Marginal Justice, 42 WESTERN POLITICAL QUARTERLY 409 (concluding that the defection of the marginal member of the minimum winning coalition on the Warren Court is best explained not by the importance of the case, but instead by that Justice's ideological proximity to members of the dissenting coalition and, secondarily, to that Justice's relative lack of competence). Other studies conclude that acquiescence was in fact more likely to occur in cases that were not "salient." Dorff \& Brenner, 54 J. POLITICS at 772, 773; Brenner, Hagle, \& Spaeth, Increasing the Size, 23 POLITY 309. Compare Brenner, 24 AM. J. POL. SCI. at 530 (finding that the percentage of total vote switches was no greater in "nonmajor" than in "major" cases, but that vote switches occurred in a higher percentage of "nonmajor" cases); Brenner, 26 AM. J. POL. SCI. at 389 (reaching similar conclusions with a different data set).

188 ALPHEUS THOMAS MASON, WILLIAM HOWARD TAFT: CHIEF JUSTICE 198 (1964); MASON, TAFT TO WARREN at 57; Alpheus Thomas Mason, The Chief Justice of the United States: Primus Inter Pares, 17 J. PUB. L. 20, 31-32 (1968).

189 Post, 85 MINN. L. REV. at 1309.

190 LEE EPSTEIN, JEFFREY A. SEGAL, HAROLD J. SPAETH, \& THOMAS WALKER, THE SUPREME COURT COMPENDIUM: DATA, DECISIONS, AND DEVELOPMENTS 147, 161 (1994).

191 Post, 85 MINN. L. REV. at 1310.

192 Post, 85 MINN. L. REV. at 1310-11, 1356; MASON, WILLIAM HOWARD TAFT at 198; William Howard Taft to Harlan F. Stone, Jan. 26, 1927, Box 76, Harlan F. Stone Papers, Manuscript Division, Library of Congress, quoted in WALTER F. MURPHY, ELEMENTS OF JUDICIAL STRATEGY 47 (1964); Danelski, The Influence of the Chief Justice, at 174.

1932 HENRY F. PRINGLE, THE LIFE AND TIMES OF WILLIAM HOWARD TAFT 1049 (1939) (Taft "shrank from all dissents, including his own"); Post, 85 MINN. L. REV. at 1311-12.

194 Urofsky, 1985 SUP. CT. REV. at 330; Post, 85 MINN. L. REV. at 1318, 1340, 1341, 1343.

195 HENRY J. ABRAHAM, THE JUDICIAL PROCESS 214-15 (2d. ed. 1968); MURPHY at 52; Post, 85 MINN. L. REV. at 1340.

196 Post, 85 MINN. L. REV. at 1341-43.

197 Post, 85 MINN. L. REV. at 1341-44; James C. McReynolds to Harlan F. Stone, Apr. 2, 1930, Box 76, Harlan F. Stone Papers, Manuscript Division, Library of Congress, quoted in Corley, Steigerwalt, \& Ward, $38 \mathrm{~J}$. SUP. CT. HIST. at 30; MURPHY at 52-53.

198 Urofsky, 1985 SUP. CT. REV. at 327, 328, 330; Post, 85 MINN. L. REV. at 1341-42, 1344-46, 1349-51; MASON, TAFT TO WARREN at 58 ("For the sake of 
harmony staunch individualists such as Holmes, Brandeis, and Stone, though disagreeing, would sometimes go along with the majority"); Northern Securities Co. v. United States, 193 U.S. 197, 400 (1904) (Holmes, J., dissenting) ("I think it useless and undesirable, as a rule, to express dissent"); ALEXANDER M. BICKEL, THE UNPUBLISHED OPINIONS OF MR. JUSTICE BRANDEIS 18 (1957) (“'Can't always dissent,' [Brandeis] said ... 'I sometimes endorse an opinion with which I do not agree."')

199 Epstein, Segal, \& Spaeth, 45 AM. J. POL. SCI. at 365. See also O'Brien, Institutional Norms, at 98.

200 Danelski, The Influence of the Chief Justice, at 174; O'Brien, Institutional Norms, at 98.

201 Danelski, The Influence of the Chief Justice, at 174.

202 In cases decided by written opinion, White dissented in $1.35 \%$, Taft in $0.93 \%$, Hughes in $2.24 \%$, Stone in $13.49 \%$, Vinson in $12.44 \%$, and Warren in $12.13 \%$. S. Sidney Ulmer, Exploring the Dissent Patterns of the Chief Justices: John Marshall to Warren Burger, in SHELDON GOLDMAN \& CHARLES M. LAMB, eds., JUDICIAL CONFLICT AND CONSENSUS: BEHAVIORAL STUDIES OF AMERICAN APPELLATE COURTS 53 (1986).

203 Post, 85 MINN. L. REV. at 1344.

204 Post, 85 MINN. L. REV. at 1344, 1348-49, 1354, 1356-57; Evan A. Evans, The Dissenting Opinion-Its Use and Abuse, 3 MO. L. REV. 120, 123-26 (1938) (quoting various criticisms of dissents made by members of the bench and bar); Alex Simpson, Jr., Dissenting Opinions, 71 U. PA. L. REV. 205, 205-06 (1923) (quoting various professional criticisms of dissenting opinions); William A. Bowen, Dissenting Opinions, 17 GREEN BAG 690, 693 (1905) ("the Dissenting Opinion is of all judicial mistakes the most injurious"). See also Ulmer, Exploring the Dissent Patterns, at 50-51 ("dissent diminishes the image of monolithic solidarity, which allegedly enhances respect for the Court and obedience to its mandates").

205 ABA Canons of Judicial Ethics, Canon 19 (1924), in LISA L. MILORD, THE DEVELOPMENT OF THE ABA JUDICIAL CODE 137 (1992). In 1972, the American Bar Association replaced the Canons with a Code of Judicial Conduct, which does not contain a provision similar to Canon 19. Wahlbeck, Spriggs II, \& Maltzman, 27 AMERICAN POLITICS QUARTERLY at $508 \mathrm{n} .1$.

206 Post, 85 MINN. L. REV. at 1284 n.55.

207 Post, 85 MINN. L. REV. at 1345. See also Caldeira \& Zorn, 42 AM. J. POL. SCI. at 877; MURPHY at 61 (“A Justice who persistently refuses to accommodate his views to those of his colleagues may come to be regarded as an obstructionist. A Justice whose dissents become levers for legislative or administrative action reversing judicial policies may come to be regarded as disloyal to the bench. It is possible that either appraisal would curtail his influence with his associates.")

208 During this period, Justices were authorized to employ a law clerk and a secretary. Pierce Butler used each to perform the duties of a law clerk, and one of them, John Cotter, wrote first drafts of most of Butler's opinions. The other Justices, however, tended to employ only one law clerk, and to do their own drafting. See Barry Cushman, The Clerks of the Four Horsemen, Part I, 39 J. SUP. CT. HIST. 386 (2014); Barry Cushman, The Clerks of the Four Horsemen, Part II, 40 J. SUP. CT. HIST. 55 (2015); MELVIN I. UROFSKY, LOUIS D. BRANDEIS: A LIFE 465 (2009). Congress did not authorize the Justices to hire two law clerks until 1941, though most of them continued to employ only one clerk until 1946. See ARTEMUS WARD \& DAVID L. WEIDEN, SORCERER'S APPRENTICES: 100 YEARS OF LAW CLERKS AT THE UNITED STATES SUPREME COURT 36-37 (2006).

209 See BRADLEY J. BEST, LAW CLERKS, SUPPORT PERSONNEL, AND THE DECLINE OF CONSENSUAL NORMS OF THE UNITED STATES SUPREME COURT, 1935-1995 at 214, 232 (2002) (finding "a positive, statistically significant relationship between the number of law clerks on the Court and the frequency of dissenting and concurring opinions"); Ley, Searles, \& Clayton, 49 TULSA L. REV. at 112-13, 121 (concluding that "the opportunity for cost-lowering effects of law clerks" is "significant to our understanding of the persistence of non-consensual norms.")

${ }^{210}$ LEE EPSTEIN, JEFFREY A. SEGAL, HAROLD J. SPAETH, \& THOMAS WALKER, THE SUPREME COURT COMPENDIUM: DATA, DECISIONS, AND DEVELOPMENTS $247-49$ ( $5^{\text {th }}$ ed. 2012). 